\title{
Endothelial Hypoxia-Inducible Factor-1 $\alpha$ Is Required for Vascular Repair and Resolution of Inflammatory Lung Injury through Forkhead Box Protein M1
}

\author{
Xiaojia Huang, ${ }^{* \dagger \ddagger}$ Xianming Zhang, ${ }^{* \dagger \ddagger}$ David X. Zhao, ${ }^{\ddagger \S}$ Jun Yin,,${ }^{\ddagger}$ Guochang Hu, Colin E. Evans, ${ }^{* \dagger \ddagger}$ and You-Yang Zhao ${ }^{* \dagger \neq \| * * \dagger \dagger}$
}

From the Program for Lung and Vascular Biology,* Stanley Manne Children's Research Institute, Ann \& Robert H. Lurie Children's Hospital of Chicago, Chicago; the Division of Critical Care, ${ }^{\dagger}$ Department of Pediatrics, the Department of Pharmacology, ${ }^{\|}$the Division of Pulmonary and Critical Care Medicine, ** Department of Medicine, and the Feinberg Cardiovascular Research Institute, ${ }^{\dagger \dagger}$ Northwestern University Feinberg School of Medicine, Chicago; the Departments of Pharmacology ${ }^{\ddagger}$ and Anesthesiology, ${ }^{\circledR}$ University of Illinois College of Medicine, Chicago; and the Department of Medicine, ${ }^{\S}$ University of Chicago, Chicago, Illinois

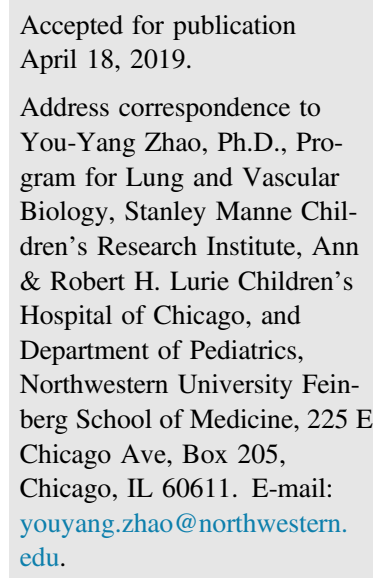

\begin{abstract}
Endothelial barrier dysfunction is a central factor in the pathogenesis of persistent lung inflammation and protein-rich edema formation, the hallmarks of acute respiratory distress syndrome. However, little is known about the molecular mechanisms that are responsible for vascular repair and resolution of inflammatory injury after sepsis challenge. Herein, we show that hypoxia-inducible factor-1 $\alpha$ (HIF-1 $1 \alpha)$, expressed in endothelial cells (ECs), is the critical transcriptional factor mediating vascular repair and resolution of inflammatory lung injury. After sepsis challenge, HIF- $1 \alpha$ but not HIF- $2 \alpha$ expression was rapidly induced in lung vascular ECs, and mice with EC-restricted disruption of Hif1 $\alpha\left(\mathrm{Hifl}_{\mathrm{f}} \mathrm{a}^{\mathrm{f} f} / \mathrm{Tie}_{\mathrm{ie}} \mathrm{Cr} \mathrm{C}^{+}\right.$) exhibited defective vascular repair, persistent inflammation, and increased mortality in contrast with the wild-type littermates after polymicrobial sepsis or endotoxemia challenge. Hifl $\mathrm{a}^{f / f} / \mathrm{Tie} 2 \mathrm{Cr} \mathrm{C}^{+}$lungs exhibited marked decrease of EC proliferation during recovery after sepsis challenge, which was associated with inhibited expression of forkhead box protein M1 (Foxm1), a reparative transcription factor. Therapeutic restoration of endothelial Foxm1 expression, via liposomal delivery of Foxm1 plasmid DNA to $\mathrm{Hifl}^{\mathrm{f} / \mathrm{f}} / \mathrm{Tie} 2 \mathrm{Cre}^{+}$mice, resulted in reactivation of the vascular repair program and improved survival. Together, our studies, for the first time, delineate the essential role of endothelial HIF-1 $\alpha$ in driving the vascular repair program. Thus, therapeutic activation of HIF- $1 \alpha$-dependent vascular repair may represent a novel and effective therapy to treat inflammatory vascular diseases, such as sepsis and acute respiratory distress syndrome. (Am J Pathol 2019, 189: 1664-1679; https://doi.org/10.1016/ j.ajpath.2019.04.014)
\end{abstract}

The healthy endothelium that lines the inner wall of blood vessels regulates the flux of fluid, proteins, and blood cells across the vessel wall into parenchymal tissue and maintains an antithrombotic and anti-inflammatory state of the microvascular bed. ${ }^{1-3}$ Endothelial injury leads to complications associated with inflammation, including increased vascular permeability, transmigration of inflammatory cells, diapedesis of erythrocytes, tissue edema, and microthrombosis. $^{4-6}$ Thus, recovery of endothelial barrier integrity is essential for maintaining vascular homeostasis and tissue fluid balance after injury. Human and animal studies have identified a key role of microvascular leakage in determining the outcome of sepsis. ${ }^{7-14}$ Targeting microvascular leakage repair mechanisms that restore endothelial barrier integrity represents a novel and effective therapeutic option for treatment of severe sepsis and related multiple organ dysfunction, such as acute respiratory distress

Supported, in part, by NIH grants R01HL123957, R01HL125350, R01HL133951, R01HL140409, and P01HL077806 (Y.-Y.Z.).

Disclosures: None declared.

Current address of X.H., Institute of Biomedical Engineering and Health Sciences, Changzhou University, Jiangsu, China; of J.Y., Department of Emergency Medicine, Zhongshan Hospital, FuDan University, Shanghai, China. 
syndrome (ARDS). ${ }^{7,8,15}$ ARDS is characterized by persistently increased lung microvascular permeability, resulting in intractable protein-rich edema and persistent lung inflammation. ${ }^{16-18}$ Current treatments for ARDS, including protective pulmonary ventilation and supportive fluid management, however, do not target the molecular and cellular mechanisms responsible for endothelial regeneration and vascular repair; and the mortality rate remains as great as $30 \%$ to $40 \% .^{17,18}$ Thus, identifying and targeting the signaling pathways responsible for endothelial recovery and vascular repair could ultimately improve clinical outcomes for sepsis and ARDS patients.

Hypoxia-inducible factors (HIFs) are critical mediators of the adaptive responses to hypoxia and ischemia. ${ }^{19-23}$ These heterodimeric proteins consist of a constitutively expressed $\beta$ subunit and an oxygen-labile $\alpha$ subunit. In normoxic conditions, the HIF- $\alpha$ subunit is hydroxylated by the HIF prolyl hydroxylases 1 to 3 and subsequently recognized by the von Hippel-Lindau protein, leading to proteasomal degradation by the ubiquitin-protein ligase complex. ${ }^{23-25}$ Under hypoxic conditions, degradation of the HIF- $\alpha$ subunit is inhibited, resulting in accumulation of the HIF- $\alpha$ subunit in the nucleus and formation of HIF complexes with the $\beta$ subunit. The HIF complex then binds to the hypoxiaresponse elements of its target genes and regulates the expression of genes essential for the adaptive responses to hypoxia and ischemia. ${ }^{19-23}$ There are three isoforms of the $\alpha$-subunit (HIF- $1 \alpha$, HIF- $2 \alpha$, and HIF- $3 \alpha$ ) and one $\beta$ subunit. A recent study has demonstrated the role of HIF- $2 \alpha$ in enhancing endothelial barrier integrity and thereby inhibiting vascular injury in response to sepsis challenge, in part through transcriptional regulation of expression of vascular endothelial-phosphotyrosine phosphatase. ${ }^{26}$ However, the role of HIF- $\alpha$ in regulating endothelial regeneration and vascular repair after injury and the specific isoform mediating this process remain unknown.

Herein, we show that expression of HIF- $1 \alpha$, but not HIF$2 \alpha$, is rapidly induced in mouse lungs after sepsis challenge. We identify the prerequisite role of endothelial HIF- $1 \alpha$ in activating endothelial regeneration and vascular repair during the recovery phase after sepsis challenge. However, endothelial HIF- $1 \alpha$ has little effect on the severity of initial injury. We also show that HIF- $1 \alpha-$ mediated vascular repair and resolution of inflammation occur in a forkhead box protein M1 (Foxm1)-dependent manner. Thus, therapeutic activation of HIF- $1 \alpha$-mediated vascular repair may represent a novel therapeutic approach for the prevention and treatment of inflammatory vascular diseases, such as sepsis and ARDS.

\section{Materials and Methods}

Mice

To generate $\mathrm{Hifla}^{\mathrm{fff}} / \mathrm{Tie} 2 \mathrm{Cr} \mathrm{C}^{+}$mice, Hifla floxed/floxed mice (catalog number 007561; Jackson Laboratory, Bar
Harbor, ME) were bred with mice expressing Cre recombinase driven by the Tie 2 promoter (catalog number 008863 ; Jackson Laboratory). Littermate wild-type (WT; $\mathrm{Cre}^{-}$) mice served as controls. Both male and female mice (aged 3 to 4 months) were used throughout. Experiments were conducted according to NIH guidelines on the use of laboratory animals. ${ }^{27}$ Studies were approved by the Institutional Animal Care and Use Committees of The University of Illinois at Chicago and Northwestern University (both in Chicago, IL).

\section{Induction of Lung Injury}

Polymicrobial sepsis was induced by cecal ligation and puncture (CLP) using a 23-gauge needle (one puncture for sublethal and two punctures for survival study). Briefly, mice were anesthetized by isoflurane inhalation ( $2.5 \%$ in oxygen). When mice were unresponsive to paw pinch, s.c. buprenorphine hydrochloride (Buprenex, $0.1 \mathrm{mg} / \mathrm{kg}$; Reckitt Benckiser Pharmaceuticals, Inc., Richmond, VA) was administered, followed by skin sterilization with povidone iodine and, subsequently, a midline abdominal incision was performed. The cecum was exposed and then ligated with a 4-0 silk tie positioned at $0.6 \mathrm{~cm}$ from the cecum tip, and then the cecal wall was punctured with a 23 -gauge needle. Sham control mice underwent anesthesia, laparotomy, and wound closure without cecal ligation or puncture. After surgery, $500 \mu \mathrm{L}$ of prewarmed saline was administered subcutaneously. Mice recovered from surgery (within 5 minutes) and received a second dose of s.c. buprenorphine hydrochloride at 8 hours after surgery.

To induce endotoxemia, mice received a single dose of i.p. lipopolysaccharide (LPS; $2.5 \mathrm{mg} / \mathrm{kg}$ body weight; Escherichia coli 055:B5; Santa Cruz Biotechnology, Dallas, TX). All mice were anesthetized with ketamine/xylazine (100:5 $\mathrm{mg} / \mathrm{kg}$ body weight, intraperitoneally) before tissue collection. For the survival study, mice were challenged with a lethal dose of LPS $(5 \mathrm{mg} / \mathrm{kg}$ ) and monitored for 6 days.

\section{Vascular Permeability Assessment}

Extravasation of Evans Blue Dye-conjugated albumin (EBA) was assessed, as previously described. ${ }^{20}$ Briefly, mice were retro-orbitally injected with EBA $(20 \mathrm{mg} / \mathrm{kg}$ body weight) at 30 minutes before tissue collection. Lungs were perfused with phosphate-buffered saline, blotted dry, and then weighed. Lung tissues were homogenized in phosphate-buffered saline $(1 \mathrm{~mL})$ and then incubated with 2 $\mathrm{mL}$ of formamide at $60^{\circ} \mathrm{C}$ for 18 hours. The homogenates were then centrifuged at $10,000 \times g$ for 30 minutes. Supernatant OD was measured at 620 and $740 \mathrm{~nm}$. Extravasated EBA in the lung homogenate was presented as $\mu \mathrm{g}$ of Evans Blue Dye per $\mathrm{g}$ of tissue.

\section{Myeloperoxidase Assay}

After perfusion free of blood, lung tissues were collected and homogenized in phosphate buffer $(50 \mathrm{mmol} / \mathrm{L})$. Homogenates 


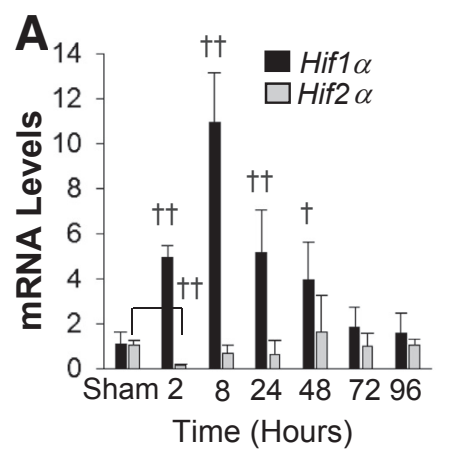

D

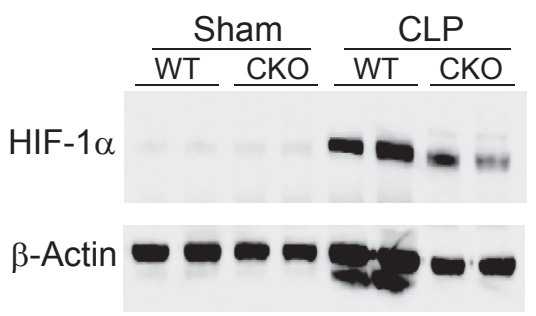

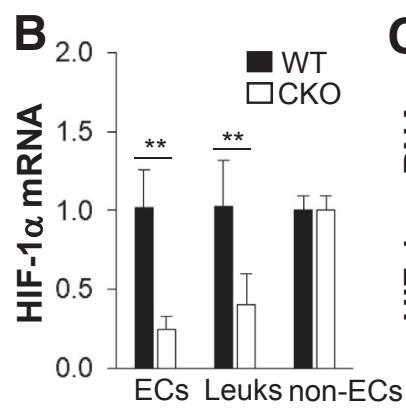
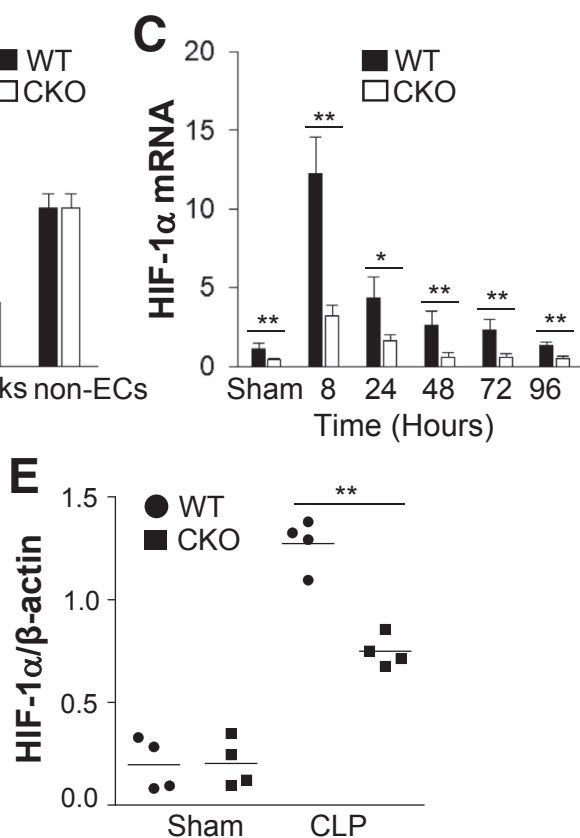

Figure 1 HIF- $1 \alpha$ rapidly induces mouse lung endothelial cells (ECS) after cecal ligation and puncture (CLP) challenge. A: Real-time quantitative RT-PCR (RT-qPCR) analysis demonstrating rapid induction of HIF- $1 \alpha$, but not HIF-2 $\alpha$, expression in lungs of wild-type (WT) mice after CLP. HIF- $2 \alpha$ expression is initially decreased at 2 hours after CLP and then returns to basal levels, whereas HIF- $1 \alpha$ expression is markedly induced and peaks at 8 hours after CLP. B: HIF$1 \alpha$ mRNA expression in isolated lung ECs $\left(\mathrm{CD} 45^{-} / \mathrm{CD} 31^{+}\right)$, leukocytes (Leuks; CD45 $\left.5^{+} / \mathrm{CD} 31^{+}\right)$, and non-ECs, including epithelial cells and fibroblasts (CD45 $/$ $\mathrm{CD}^{-} 1^{-}$), from WT and $\mathrm{Hif1}^{\mathrm{f} / f} / \mathrm{Tie}^{2} \mathrm{Cre} e^{+}$(CKO) mouse lungs by fluorescence-activated cell sorting. C: RT-qPCR analysis demonstrating inhibited HIF-1 $\alpha$ induction in Hif1 $a^{f / f} /$ Tie2Cre lungs after CLP challenge. D: Representative Western blot analysis demonstrating marked inhibition of HIF-1 $\alpha$ protein expression in CKO mouse lungs at 8 hours after CLP compared with WT lungs. $\beta$-Actin was used as a loading control. E: Quantification of Western blot analysis band intensity using ImageJ software version 1.51a (NIH, Bethesda, MD; $h$ ttp://imagej. nih.gov/ij). Data are expressed as means \pm SD $(\mathbf{A}-\mathbf{C})$ and means (E). $n=5$ mice per group (A); $n=4$ mice (B, demonstrating Tie2Cre-mediated Hif1a deletion in ECs and leukocytes, and $\mathbf{C}$, per group). ${ }^{*} P<0.05$, ${ }^{* *} P<0.01$ ( $t$-test); ${ }^{\dagger} P<0.05,{ }^{\dagger \dagger} P<0.01$ compared with WT-sham (one-way analysis of variance with a Tukey's post hoc analysis for multiple-group comparisons and $t$-test for two-group comparison).

were centrifuged at $15,000 \times g$ for 20 minutes at $4^{\circ} \mathrm{C}$. The pellets were resuspended in phosphate buffer containing $0.5 \%$ hexadecyl trimethylammonium bromide and subjected to one cycle of freeze thawing. The pellets were subsequently homogenized and centrifuged again. Absorbance was measured at $460 \mathrm{~nm}$ every 15 seconds for 3 minutes, and data are expressed as $\Delta \mathrm{OD}_{460} / \mathrm{min}$ per gram lung tissue.

\section{Cell Proliferation and Apoptosis Assays}

Mice received $75 \mathrm{mg} / \mathrm{kg}$ of 5-bromo-2-deoxyuridine (Sigma-Aldrich, St. Louis, MO) at 5 hours before tissue collection. Lung cryosections ( $7 \mu \mathrm{m}$ thick) were immunostained for 16 hours with anti-5-bromo-2-deoxyuridine (dilution 1:3; BD Biosciences, San Jose, CA), followed with Alexa Flour 488-conjugated secondary antibody (dilution 1:100; Life Technologies, Grand Island, NY). Endothelial cells (ECs) were immunostained with anti-CD31 (dilution 1:40; Abcam, Cambridge, MA) and anti-von Willebrand factor (dilution 1:250; Sigma-Aldrich) antibodies overnight at $4^{\circ} \mathrm{C}$, then incubated with Alexa Fluor 594-conjugated secondary antibody (dilution 1:100; Life Technologies). Nuclei were counterstained with DAPI (Life Technologies). Sections were imaged with confocal microscope LSM510 equipped with a $63 \times 1.2$ numerical aperture objective lens (Carl Zeiss, Inc., Oberkochem, Germany).

For the lung apoptosis assay, lung cryosections were stained with terminal deoxynucleotidyl transferase-mediated dUTP nick-end labeling using the In Situ Cell Death Detection fluorescein kit (Roche Applied Science, Mannheim, Germany). ECs were immunostained with antiCD31 and anti-von Willebrand factor antibodies, and nuclei were counterstained with DAPI.

\section{Fluorescence-Activated Cell Sorting Analysis}

After phosphate-buffered saline perfusion, lung tissues were cut into small pieces and then incubated with $1 \mathrm{mg} / \mathrm{mL}$ collagenase A (Roche Applied Science) for 1 hour at $37^{\circ} \mathrm{C}$ in a shaking water bath (200 rpm). After digestion, the tissue was dispersed to a single-cell preparation using the gentleMACS Dissociator (Miltenyi Biotec, Bergisch Gladbach, Germany) with lung program 2 . The cells were then filtered using a $40-\mu \mathrm{m}$ nylon cell strainer and blocked with $20 \%$ fetal bovine serum for 30 minutes. After incubation with $\mathrm{Fc}$ blocker ( $1 \mu \mathrm{g} / 10^{6}$ cells; BD Biosciences), the cells were immunostained with anti-CD45-phycoerythrin (dilution 1:800; BioLegend, San Diego, CA) and/or 
A
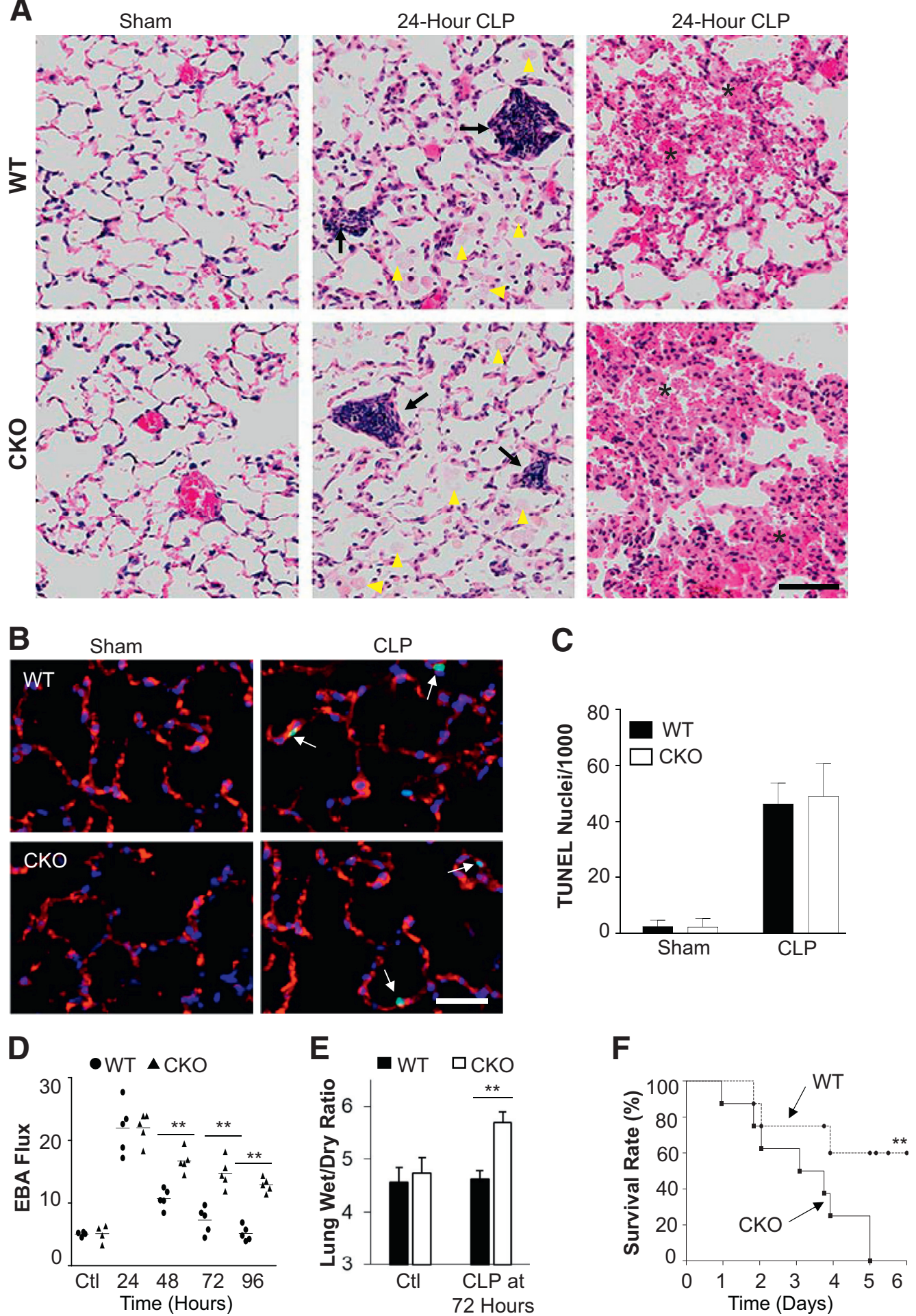

Figure 2 Impaired lung vascular repair and increased mortality in $\mathrm{Hif1}_{\mathrm{f}}^{f / f} / \mathrm{Tie} 2 \mathrm{Cre}{ }^{+}$(CKO) mice after cecal ligation and puncture (CLP) challenge. A: Representative hematoxylin and eosin staining showing characteristics of the pathology of acute lung injury, including protein leakage (arrowheads), alveolar septum thickening, and inflammatory cell infiltration (arrows), and hemorrhaging (asterisks) at 24 hours after CLP in both wild-type (WT) and Hif $1 a^{f / f} / T_{i e 2 C r e}+$ mice. B: Representative micrographs of terminal deoxynucleotidyl transferase-mediated dUTP nick-end labeling (TUNEL) staining showing apoptosis (green nuclei) at 24 hours after CLP in WT and Hif1 $a^{f / f} /$ Tie2Cre $^{+}$mouse lungs. Endothelial cells (ECs) were immunostained with anti-CD31 and anti-von Willebrand factor (red). Apoptotic nuclei were stained with TUNEL (green). Nuclei were counterstained with DAPI (blue). Arrows indicate apoptotic ECs. C: Quantification of TUNEL-positive ECs. D: Pulmonary transvascular Evans Blue Dye-conjugated albumin (EBA) flux demonstrating defective vascular

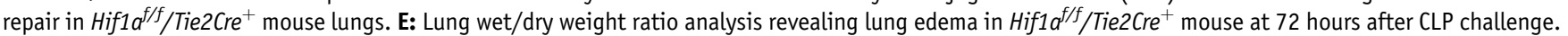
F: $\mathrm{Hif1} \mathrm{a}^{f / f} / \mathrm{Tie}^{\mathrm{C}} \mathrm{Cr}^{+}$mice exhibited greater mortality rate after CLP challenge. Mortality rate was monitored for 6 days after CLP. Data are expressed as means $\pm \mathrm{SD}(\mathbf{C}$ and $\mathbf{E})$ or means (D). $n=5$ mice per group $(\mathbf{C}$ and $\mathbf{E}) ; n=10$ mice per group $(\mathbf{F})$. ${ }^{*} P<0.01$ [one-way analysis of variance with Tukey's post-hoc analysis (D), $t$-test $(\mathbf{E})$, and Mantel-Cox test $(\mathbf{F})]$. Scale bar $=100 \mu \mathrm{m}(\mathbf{A}$ and $\mathbf{B})$. Ctl, control. 
anti-CD31-antigen-presenting cell (dilution 1:600; BD Biosciences) for 45 minutes at room temperature. Cells were then subject to fluorescence-activated cell sorting (Moflo Asrtios machine; Beckman Coulter, Brea, CA) to collect $\mathrm{CD}_{4}{ }^{-} \mathrm{CD} 31^{+} \quad$ (ECs), $\mathrm{CD}^{+} 5^{+}$(leukocytes), and $\mathrm{CD} 45^{-} \mathrm{CD} 31^{-}$(non-ECs, including epithelial cells, smooth muscle cells, and fibroblasts).

\section{Endothelial Cell Isolation}

ECs from mouse lungs were isolated using magneticactivated cell sorting. Lung tissues cut into small pieces were incubated with $1 \mathrm{mg} / \mathrm{mL}$ collagenase A (Roche Applied Science) for 1 hour at $37^{\circ} \mathrm{C}$ in a shaking water bath (200 rpm). The tissue was then dispersed to a single-cell preparation using the gentleMACS Dissociator with lung program 2 and filtered with a $40-\mu \mathrm{m}$ nylon cell strainer. The single-cell preparation was then blocked with $20 \%$ fetal bovine serum for 30 minutes and incubated with anti-CD31 antibody for 30 minutes at room temperature, followed with anti-rat IgG-conjugated Dynabeads (Invitrogen, Carlsbad, CA) for 30 minutes. ECs were collected for RNA isolation.

\section{Molecular Analysis}

Total RNA was isolated with an RNeasy Mini kit plus DNase I digestion (Qiagen, Valencia, CA). After reverse transcription, quantitative RT-PCR analysis was performed using a sequence detection system (ABI Prism 7500; Life Technologies) with SYBR Green master mix (Roche Diagnostics, Indianapolis, IN). The following mouse primers were used for analysis: Hifla, 5'-TGATGTGGGTGCTGGTGTC-3' (forward) and 5'-TTGTGTTGGGGCAGTACTG-3' (reverse); intercellular adhesion molecule 1, 5'-GTCTCGGAAGGGAGCCAAGTA- $3^{\prime}$ (forward) and 5'-CTCGACGCCGCTCAGAAGAA- $3^{\prime}$ (reverse); tumor necrosis factor- $\alpha, 5^{\prime}$ ATGCTGGGACAGTGACCTGG-3' (forward) and $5^{\prime}$ CCTTGATGGTGGTGCATGAT- $3^{\prime}$ (reverse); IL-6, 5'TCCAGTTGCCTTCTTGGGACTG- $3^{\prime}$ (forward) and $5^{\prime}$ AGCCTCCGACTTGTGGAAGTGGT-3' (reverse); inducible nitric oxide synthase, 5'-ACATCAGGTCGGCCATCACT- $3^{\prime}$ (forward) and $5^{\prime}$-CGTACCGGATGAGCTGTGAATT- $3^{\prime}$ (reverse); Cxcl12, 5'-CCAAGAGTACCTGGAGAAAGC- $3^{\prime}$ (forward) and $5^{\prime}$-AGTTACAAAGCGCCAGAGCA-3' (reverse); $C d c 25 c, 5^{\prime}$-TGAAGCATCTGGGCAGTCCCATTA-3' (forward) and 5'-GGCAGCACACACACCTTTGAGAAA-3' (reverse); Ccna2, 5'-AATGCAGCTGTCTCTTTACCCGCA-3' (forward) and 5'-CCTCCATTTCCCTAAGGTACGTGT-3' (reverse); Ccnf, $5^{\prime}$ ACAAGCCTGTGTCTTCACCTGACT-3' (forward) and $5^{\prime}$ ACGCGCACCAAGTCCTCGTATTTA-3' (reverse); Ccnb1, 5'-TGAACCAGAGGTGGAACTTGCTGA-3' (forward) and $5^{\prime}$-AGATGTTTCCATCGGGCTTGGAGA- $3^{\prime}$ (reverse); p21Cipl, 5'-ACTACCAGCTGTGGGGTGAG-3' (forward) and $5^{\prime}$-TCGGACATCACCAGGATTGG-3' (reverse); p27Kipl, 5'-CCTTCGACGCCAGACGTAAA-3' (forward) and $5^{\prime}$-TCAGTGCTTATACAGGATGTCCA-3 ${ }^{\prime}$ (reverse); and cyclophilin, 5'-CTTGTCCATGGCAAATGCTG- $3^{\prime}$ (forward) and $5^{\prime}$-TGATCTTCTTGCTGGTCTTGC-3' (reverse). Gene expression was normalized to mouse cyclophilin. The following human primers were used: FOXM1, 5'-GGAGGAAATGCCACACTTAGCG-3' (forward) and $5^{\prime}$-TAGGACTTCTTGGGTCTTGGGGTG-3' (reverse); HIF1A, 5'-TTACAGCAGCCAGACGATCATG-3' (forward) and 5'-TGGTCAGCTGTGGTAATCCACT-3' (reverse); HIF2A, 5'-CTGATGGCCATGAACAGCATCT- $3^{\prime}$ (forward) and 5'-TCCTCGAAGTTCTGATTCCCGA-3' (reverse); and 18s rRNA, 5'-TTCCGACCATAAACGATGCCGA-3' (forward) and 5'-GACTTTGGTTTCCCGGAAGCTG-3' (reverse). Human gene expression was normalized to human 18S rRNA.

For determination of protein levels, lung tissues were homogenized in radioimmunoprecipitation assay buffer with proteinase and phosphatase inhibitors (Sigma-Aldrich). Supernatant was collected after centrifugation $(21,000 \times g$ for 30 minutes at $4{ }^{\circ} \mathrm{C}$ ), and protein concentration was determined with a bicinchoninic acid protein assay kit (Thermo Fisher Scientific, Rockford, IL). Each sample of $30 \mu \mathrm{g}$ protein was loaded and separated onto a $10 \%$ SDS-PAGE gel. After protein transfer, the polyvinylidene difluoride membranes were blocked with 5\% skim milk and then incubated with anti-HIF-1 $\alpha$ (dilution 1:500; Novus Biologicals, Centennial, CO), anti-HIF-2 $\alpha$ (dilution 1:100; Novus Biologicals), antiFoxm1 (dilution 1:500; Santa Cruz Biotechnology), and anti- $\beta$-actin (dilution 1:3000; BD Biosciences) antibodies overnight at $4^{\circ} \mathrm{C}$. The membranes were next incubated with horseradish peroxidase-conjugated secondary antibodies, and immunoblots were visualized with an enhanced chemiluminescence reagent (Thermo Fisher Scientific).

\section{Histology}

Lung tissues were fixed by 5 minutes of instillation with $10 \%$ formalin through tracheal catheterization at a transpulmonary pressure of $15 \mathrm{~cm} \mathrm{H}_{2} \mathrm{O}$ and then agitated overnight at room temperature. After processing, the paraffin-embedded tissues were divided into section $(5 \mu \mathrm{m}$ thick) and stained with hematoxylin and eosin.

\section{Irradiation and Bone Marrow Transplantation}

WT or Hifla ${ }^{\mathrm{ff}} / \mathrm{Tie} 2 \mathrm{Cr} \mathrm{C}^{+}$mice (aged 6 weeks) were irradiated ( $750 \mathrm{cGy} /$ mouse). At 3 hours after irradiation, the mice were transplanted through tail vein injection with $1 \times 10^{7}$ bone marrow cells isolated from $\mathrm{Hifla}^{\text {fff }} / \mathrm{Tie}^{2} \mathrm{Cre}^{+}$or WT mice in $150 \mu \mathrm{L}$ of phosphate-buffered saline. Mice were used at the age of 3 months. To verify the efficacy of bone marrow reconstitution, bone marrow cells were also isolated from chimeric mice. Genomic DNA was extracted for realtime quantitative PCR analysis of the Sry gene. Autosomal gene Nmel was used for internal control. The following mouse primers were used for quantitative PCR analysis: Sry, 

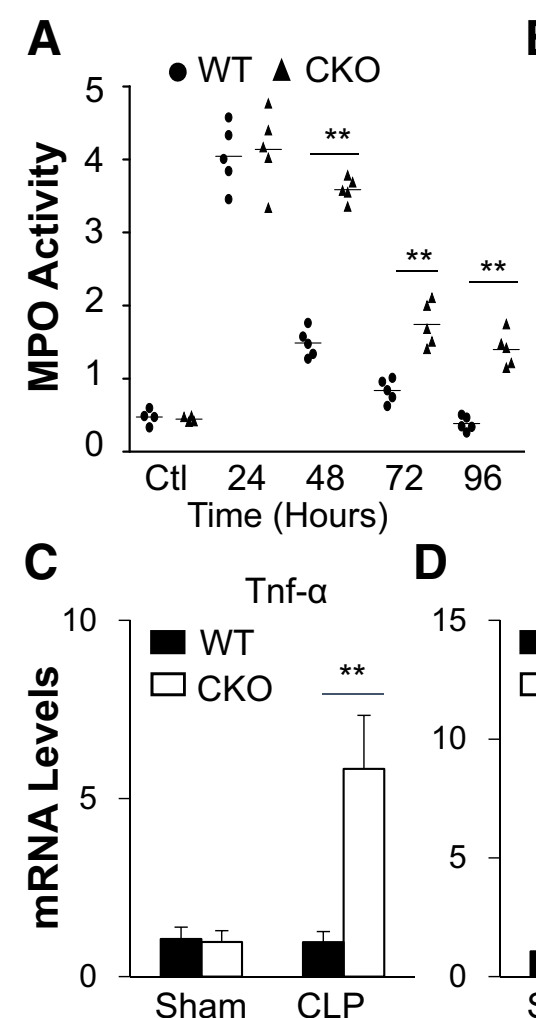

B

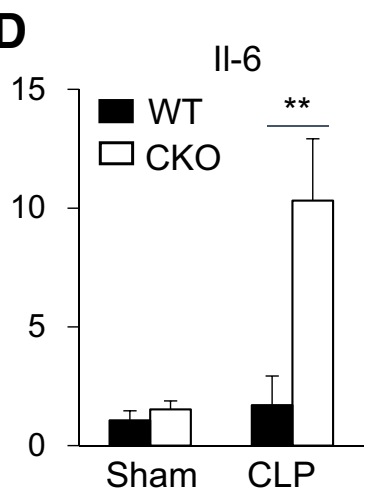

WT

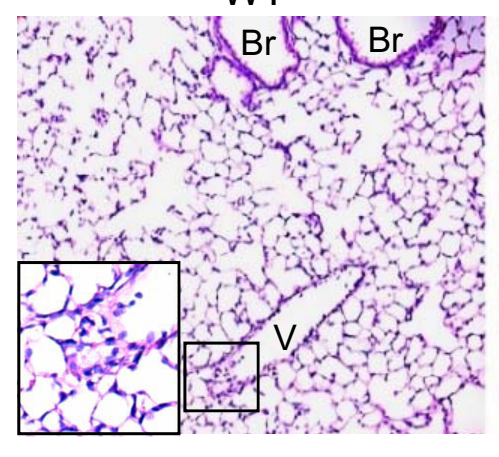

CKO

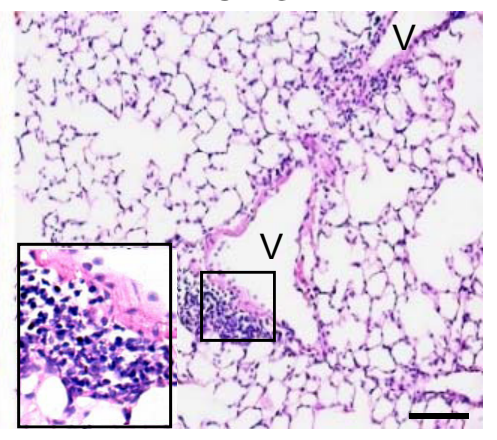

E
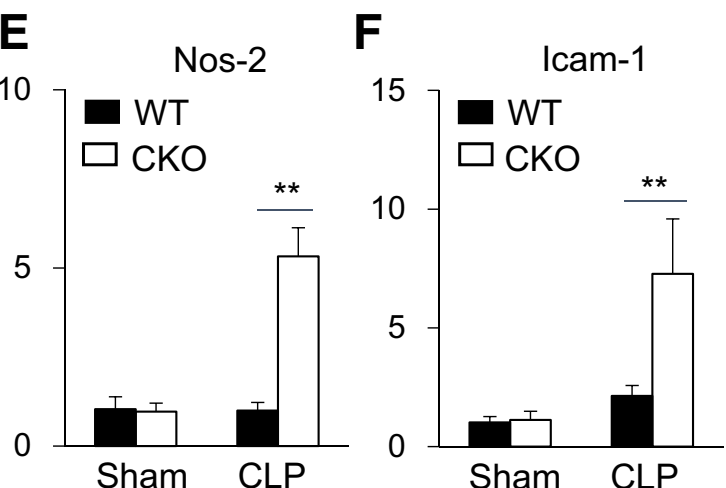

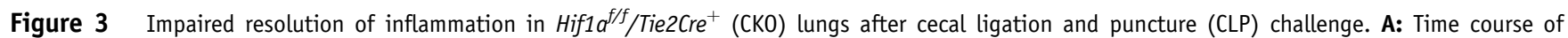
myeloperoxidase (MPO) activity in mouse lungs after CLP challenge. B: Representative micrographs of hematoxylin and eosin staining of lung sections showing perivascular leukocyte infiltration in $\mathrm{Hif1} 1 \mathrm{f}^{f / f} / \mathrm{Tie}_{\mathrm{Cre}} \mathrm{C}^{+}$mouse lungs at 72 hours after CLP. The boxed areas are shown at higher magnification in the insets in

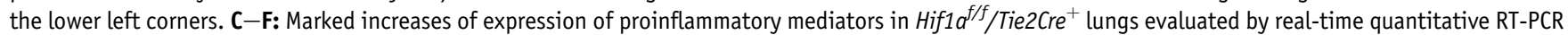
analysis. At 72 hours after CLP, mouse lungs were collected for analysis. Data are expressed as means (A) or means \pm SD (C-F). $n=4$ mice per group (C-F). ${ }^{* * P}<0.01$ [one-way analysis of variance with Tukey's post-hoc analysis $(\mathbf{A})$ or $t$-test $(\mathbf{C}-\mathbf{F})$ ]. Scale bar $=50 \mu \mathrm{m}(\mathbf{B})$. Br, bronchiole; Icam-1, intercellular adhesion molecule 1; Nos-2, inducible nitric oxide synthase; Tnf- $\alpha$, tumor necrosis factor- $\alpha$ V, vessel; WT, wild type.

5'-GCTGGGATGCAGGTGGAAAA-3' (forward) and 5'CCCTCCGATGAGGCTGATATT-3' (reverse); and Nmel, $5^{\prime}$-ACAGCTCTGCATTCCTTACC-3' (forward) and $5^{\prime}$ AGAACAGAACACAGGTGATAGG-3' (reverse).

\section{RNA Sequencing and Bioinformatics Analysis}

RNA sequencing was performed by the University of Chicago (Chicago, IL) genomics core facility. Briefly, RNA quality was confirmed using an Agilent Bio-analyzer (Agilent Technologies Inc., Santa Clara, CA). RNA-sequencing libraries were generated using TruSeq stranded total RNA LT (with RiboZero), RS-122-2301 (Illumina, San Diego, CA). Samples were sequenced using an Illumina Hiseq2500 with a single end read length of $50 \mathrm{bp}$. For analysis, raw reads were trimmed to a minimal Q20 (the cutoff value of the sequencing quality for each base) using trimmomatic version 0.32 (http://www.usadellab.org/cms/?page $=$ trimmomatic). To remove any remaining ribosomal sequences, an initial alignment against mouse rRNA sequences was performed using bowtie2 version 2.3.4.2 (http://bowtie-bio.sourceforge.net/bowtie2/index.shtml). By using University of California Santa Cruz Refseq annotations, the remaining reads against the reference genome plus the transcriptome sequence were aligned with TopHat2 version 2.1.1 (https://ccb.jhu.edu/softwarel tophat/index.shtml). Gene expression was quantified using CuffNorm version 2.2.1 (http://cole-trapnell-lab.github.io/ cufflinks/cuffnorm). Differential expression changes and $P$ and $\mathrm{q}$ values between groups were calculated using CuffDiff version 2.2.1 (http://cole-trapnell-lab.github.io/ cufflinks/cuffdiff).

Liposome-Mediated Transduction of Plasmid DNA into Lung Vascular ECs in Mice

To make liposomes, a mixture of dimethyldioctadecylammonium bromide and cholesterol $(1: 1 \mathrm{~mol} / \mathrm{L}$ ratio $)$ was dried using a Rotavaporator (BUCHI, New Castle, DE) and then dissolved in 5\% glucose, followed by sonication for 20 minutes. The plasmid DNA expressing Foxm1 under the control of the human $\mathrm{CDH} 5$ promoter (or empty vector) and liposomes were combined at $1 \mu \mathrm{g}$ DNA to $8 \mathrm{nmol}$ liposomes. The DNA/liposome complex (50 $\mu \mathrm{g}$ of DNA/mouse) was then administered intravenously at 12 hours after CLP challenge. 

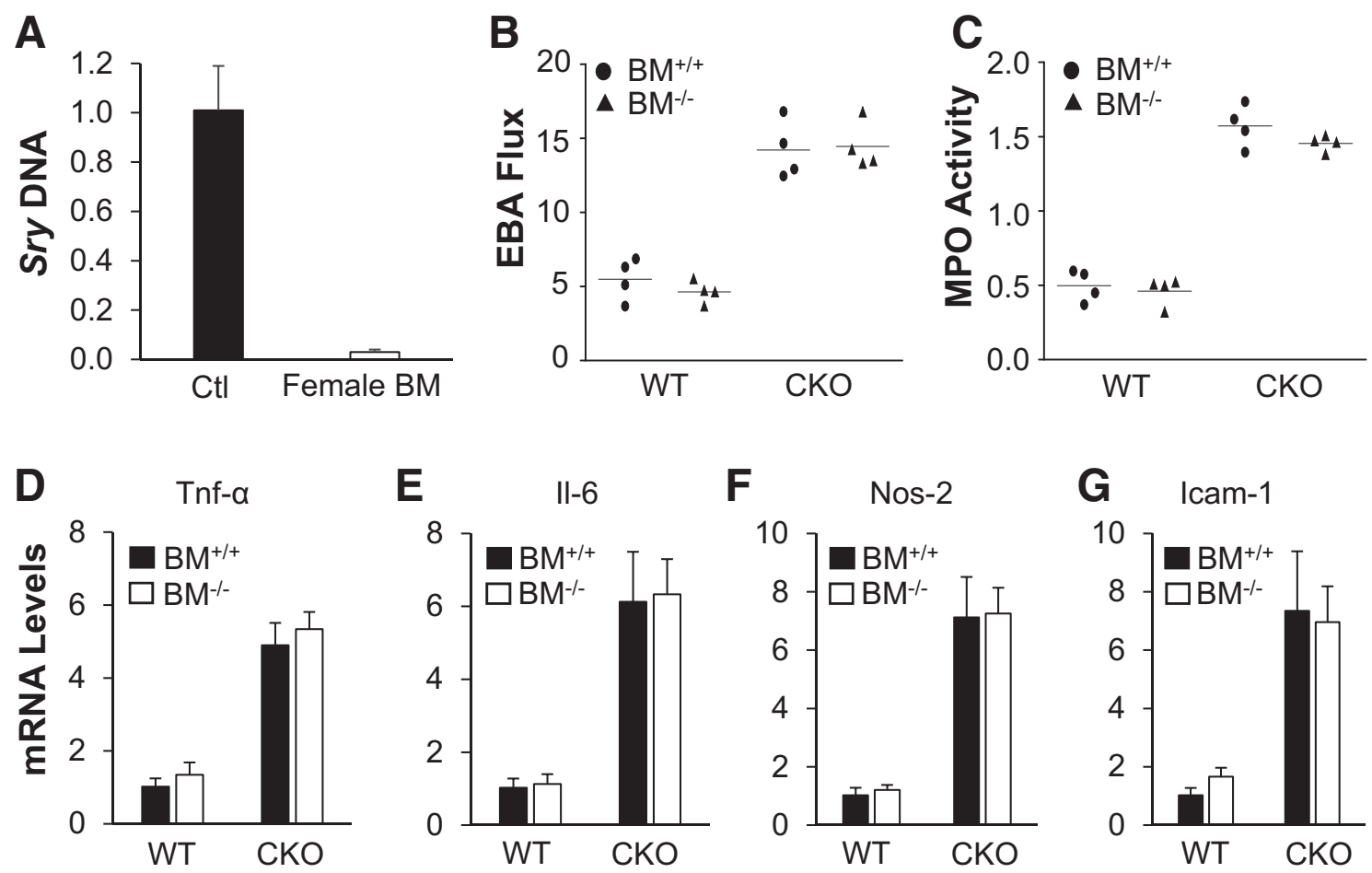

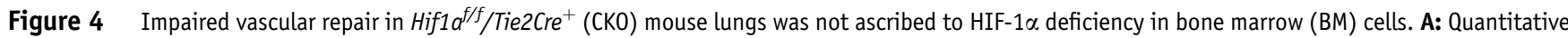
PCR analysis demonstrating $>95 \%$ efficiency of bone marrow reconstitution. Bone marrow cells from wild-type (WT) female mice were transplanted to lethally irradiated $\mathrm{Hifl}_{\mathrm{f}}^{\mathrm{f} f} / \mathrm{Tie} 2 \mathrm{Cre} e^{+}$male mice. Six weeks after transplantation, bone marrow samples from these chimeric male mice and WT male mice [positive control (Ctl)] were isolated for genomic DNA isolation and PCR analysis of Y-chromosome-specific gene Sry. B: Defective vascular repair in lungs of Hif1 $a^{f / f} /$

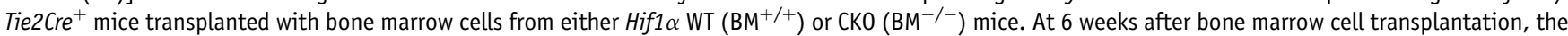
mice were challenged with cecal ligation and puncture (CLP). At 72 hours after CLP, lung tissues were collected for transvascular Evans Blue Dye-conjugated albumin (EBA) flux measurement. C: Lung myeloperoxidase (MP0) activity measurement (72 hours after CLP). D-G: Real-time quantitative RT-PCR analysis demonstrating increased expression of proinflammatory mediators in Hif1 $a^{f / f} /$ Tie2Cre $^{+}$mouse lungs reconstituted with either WT or CKO bone marrow cells at 72 hours after CLP challenge. Data are expressed as means \pm SD (A and $\mathbf{D}-\mathbf{G})$ or means (B and $\mathbf{C}) . n=4$ mice per group (A and $\mathbf{D}-\mathbf{G})$. Icam-1, intercellular adhesion molecule 1 ; Nos-2, inducible nitric oxide synthase; Tnf- $\alpha$, tumor necrosis factor $-\alpha$.

\section{Statistical Analysis}

Data are means \pm SD in bar graphs. Differences were assessed using one-way analysis of variance with a Tukey's post hoc analysis for multiple-group comparisons. Pairwise comparisons were analyzed using two-tailed unpaired $t$ tests. Statistical analysis for the mortality study was performed using the log-rank (Mantel-Cox) test. $P<0.05$ is considered as statistically significant.

\section{Results}

\section{Endothelial HIF- $1 \alpha$ Is Required for Vascular Repair after Polymicrobial Sepsis}

The expression of HIF- $1 \alpha$ and HIF- $2 \alpha$ was first assessed in lung tissues after sepsis challenge induced by CLP, which induces polymicrobial sepsis, a clinically relevant murine model of sepsis. ${ }^{28-30}$ Real-time quantitative RT-PCR analysis revealed a rapid induction of HIF- $1 \alpha$, but not HIF-2 $\alpha$, expression in WT mouse lungs after CLP challenge, which occurred as early as 2 hours and peaked at 8 hours after CLP (Figure 1A). Thus, a mouse model with EC- restricted disruption of HIF-1 $\alpha$ ( $\left.\mathrm{Hifla}^{\mathrm{fff}} / \mathrm{Tie} \mathrm{Cr} \mathrm{Cr}^{+}\right)$was generated to study the role of endothelial HIF- $1 \alpha$ in regulating endothelial injury and vascular repair.

Mice with Hifla floxed (Hifla $a^{\text {fff }}$ ) allele were bred with Tie2 promoter/enhancer-driven Cre recombinase (Cre) (Tie2Cre) transgenic mice to inactivate HIF- $1 \alpha$ in mouse endothelium. ${ }^{31}$ Unlike global Hifla-null mutation mice, ${ }^{32} \mathrm{Hifl}^{\mathrm{fff}} / \mathrm{Tie}_{\mathrm{i}} \mathrm{Cre}^{+}$ mice were born in a mendelian ratio and indistinguishable from their Hifla ${ }^{\text {fff }}$ WT littermates. Hifl $a^{\text {fff }} / \mathrm{Tie} \mathrm{Cr} \mathrm{Cr}^{+}$mice grew to adulthood, living as long as WT mice (at least 20 months). HIF$1 \alpha$ mRNA expression was decreased by approximately $80 \%$ in pulmonary ECs (Figure 1B). Considering the purity of the isolated ECs (90\%), a 90\% deletion efficiency was expected. In $\mathrm{Hifla}^{\mathrm{fff}} / \mathrm{Tie} 2 \mathrm{Cre}^{+}$lungs, HIF-1 $\alpha$ expression was also markedly inhibited at various times after CLP challenge compared with WT lungs (Figure 1C). Western blot analysis also demonstrated induced HIF- $1 \alpha$ protein expression in WT lungs, which was markedly inhibited in $\mathrm{Hifla}^{\mathrm{fff}} / \mathrm{Tie}^{\mathrm{CCr} \mathrm{C}^{+}}$lungs (Figure 1, D and E). However, HIF- $2 \alpha$ protein expression was not inhibited in $\mathrm{Hifla}^{\mathrm{fff}} / \mathrm{Tie} 2 \mathrm{Cre}^{+}$lungs (Supplemental Figure S1), indicating isoform-specific gene deletion.

Histology examination revealed similar injury, including septal thickening, leukocyte infiltration, protein edema, and 
A

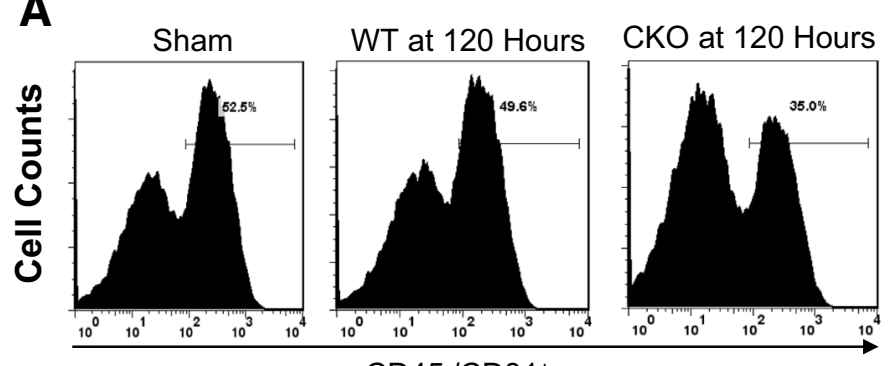

$\mathrm{CD} 45 / \mathrm{CD} 31^{+}$

C
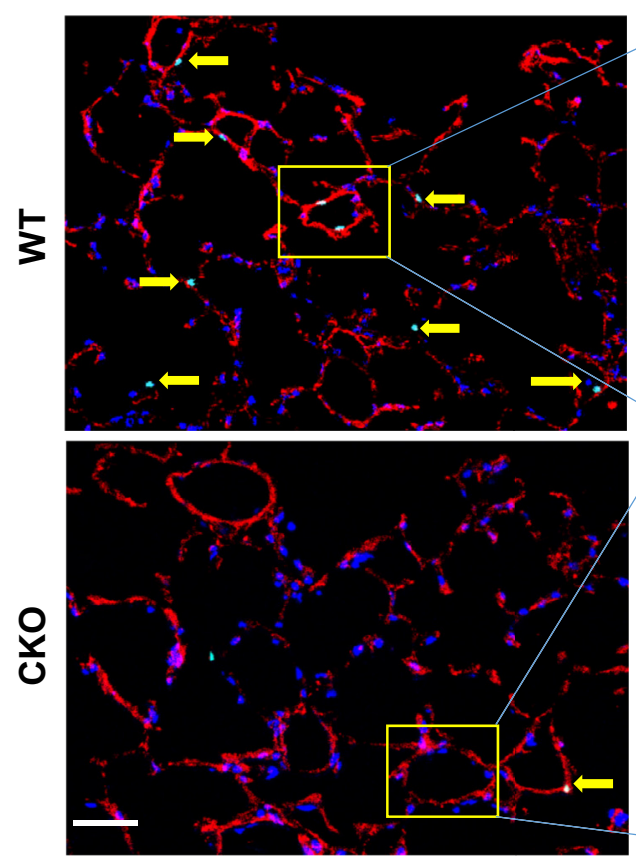

B

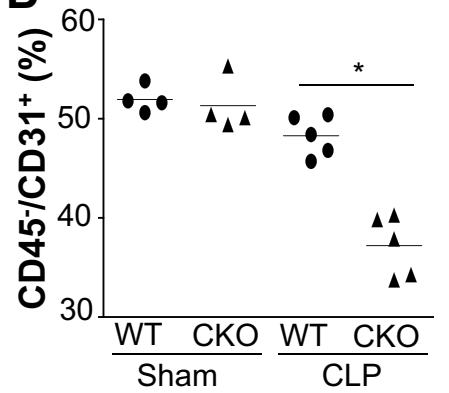

D

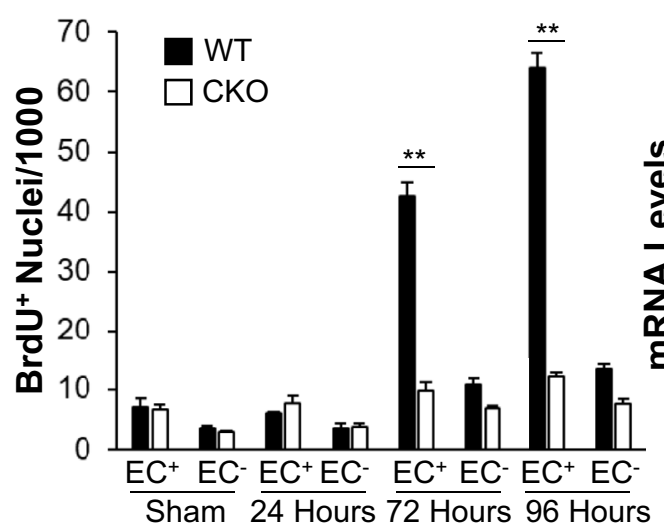

E
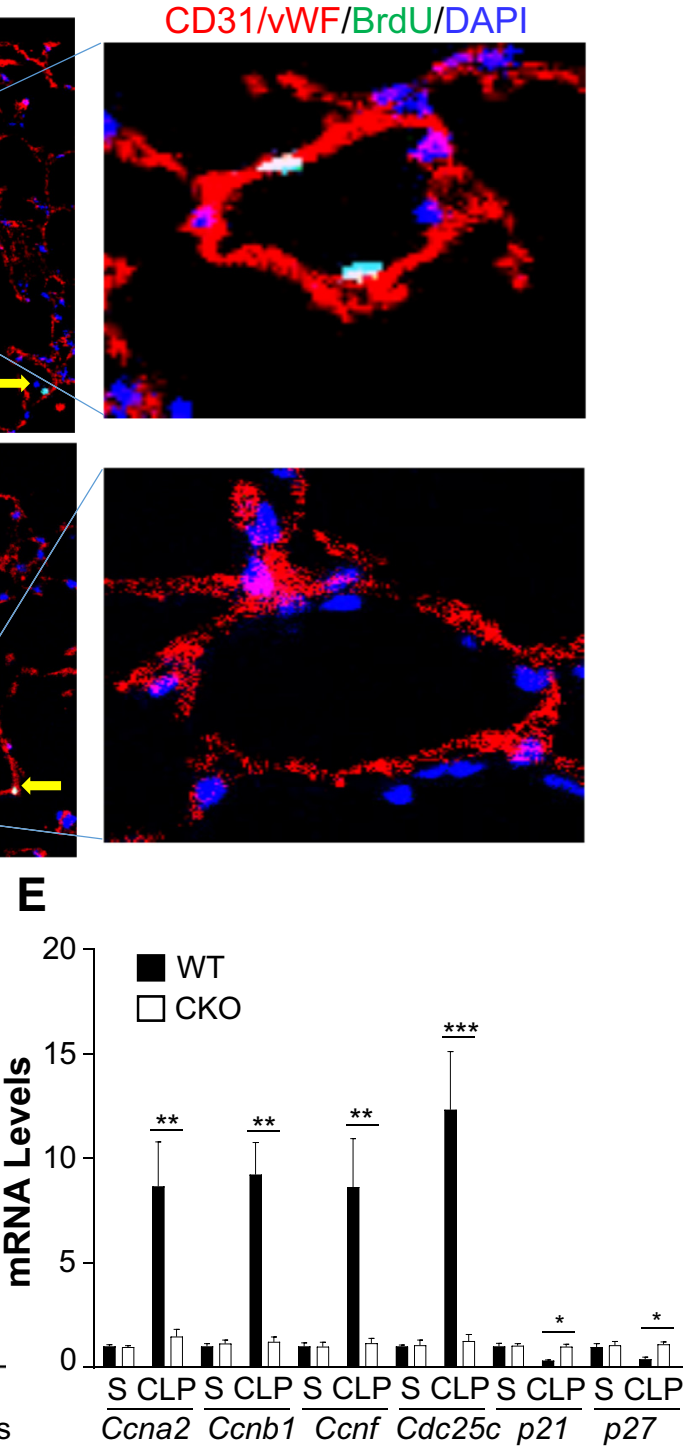

Figure 5 Defective endothelial regeneration in $\mathrm{Hif1}^{\mathrm{f} / \mathrm{f}} / \mathrm{Tie} \mathrm{Cre}+(\mathrm{CKO})$ mouse lungs after cecal ligation and puncture (CLP) challenge. A and B: Flow cytometry quantification of endothelial cells (ECs; $C D 45^{-} / \mathrm{CD}^{+} 1^{+}$) in mouse lungs at 120 hours after CLP or sham (S). At 120 hours after CLP or sham, lung tissues were collected for digestion and dissociation. Freshly prepared lung cells were immunostained with anti-CD45 and anti-CD31 antibodies for fluorescence-activated cell sorting analysis by gating $\mathrm{CD}_{4} 5^{-}$cells. A: Representative histograms showing percentage of ECs in mouse lungs. B: Quantification of ECs (\% CD45- ${ }^{-} D 31^{+}$in total CD45 cells) in mouse lungs. C: Representative micrographs showing EC proliferation. Cryosections of lungs (5 $\mu \mathrm{m}$ thick) collected at 96 hours after CLP were immunostained with anti-5-bromo-2-deoxyuridine (BrdU) antibody to identify proliferating cells (green) and with anti-CD31 and anti-von Willebrand factor (VWF) antibodies to identify ECs (red). Nuclei were counterstained with DAPI (blue). The boxed areas in the left panels are shown at higher magnification in the right panels. Arrows point to proliferating ECs. D: Quantification of cell proliferation in mouse lungs. Three consecutive cryosections from each mouse lung were examined; the average number of BrdU-positive nuclei was used. BrdU was administered intraperitoneally to mice at 5 hours before tissue collection. E: Expression of genes regulating cell cycle progression determined by real-time quantitative RT-PCR (RT-qPCR) analysis. At 96 hours after CLP, lung ECs were isolated for RNA extraction and RT-qPCR analysis. Data are expressed as means (B) or means \pm SD $(\mathbf{D}$ and $\mathbf{E}) . n=4$ (D and $\mathbf{E})$. ${ }^{*} P<0.05,{ }^{*} P<0.01$, and ${ }^{* * *} P<0.001$ (t-test). Scale bar $=50 \mu \mathrm{m}$ (C). WT, wild type. 
hemorrhaging, in WT and Hiflaff/Tie2Cre ${ }^{+}$lungs at 24 hours after CLP (Figure 2A). Terminal deoxynucleotidyl transferase-mediated dUTP nick-end labeling staining also showed a similar degree of EC apoptosis at 24 hours after CLP (Figure 2, B and C). Vascular permeability was assessed by determination of pulmonary transvascular flux of EBA. ${ }^{13}$ In sham-operated mice, EBA flux in WT and $\mathrm{Hifla}^{\mathrm{fff}} / \mathrm{Tie}_{\mathrm{TCr}}{ }^{+}$mice was similar at the basal levels, indicating that healthy $\mathrm{Hifla}^{\text {fff }} / \mathrm{Tie} 2 \mathrm{Cr} e^{+}$mice have normal lung vascular integrity. Pulmonary vascular EBA flux increased by fourfold to fivefold and peaked at 24 hours after CLP challenge in $\mathrm{Hifla}^{\mathrm{ff}} / \mathrm{Tie} 2 \mathrm{Cre}^{+}$lungs, similar to WT lungs (Figure 2D). EBA flux in WT lungs returned to basal levels at 72 and 96 hours after CLP, indicating full recovery, whereas $\mathrm{Hifla}^{\mathrm{ff}} / \mathrm{Tie} 2 \mathrm{Cre}^{+}$lungs exhibited persistent vascular leakiness. These data demonstrate a similar degree of injury in WT and Hifla $a^{f f} / \mathrm{Tie} 2 \mathrm{Cre}^{+}$lungs during the injury phase; the critical difference in Hifla $a^{f f} / \mathrm{Tie} \mathrm{Cre}^{+}$lungs compared with WT was at the repair phase. The $\mathrm{Hifla}^{\mathrm{fff}} / \mathrm{Tie}_{\mathrm{T}} \mathrm{Cr} \mathrm{Cr}^{+}$lungs exhibited impaired

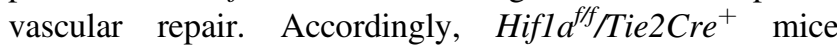
exhibited a marked increase of lung wet/dry weight ratio, indicating lung edema at 72 hours after CLP (Figure 2E). $\mathrm{Hifla}^{\mathrm{fff}} / \mathrm{Tie} \mathrm{Cre}^{+}$mice also exhibited a marked increase in mortality after CLP challenge (Figure 2F); all of the Hifla ${ }^{f f} / \mathrm{Tie}^{2} \mathrm{Cre}^{+}$mice had died within 5 days after CLP, whereas only $40 \%$ of WT mice had died at this time.

\section{Endothelial Disruption of HIF-1 $\alpha$ Results in Impaired Resolution of Lung Inflammation after Sepsis-Induced Injury}

To assess pulmonary inflammation, lung myeloperoxidase (MPO) activity, indicative of neutrophil sequestration, and expression of inflammatory cytokines were quantified. Lung MPO activity was similarly increased in Hifla $a^{\text {fff }}$ / $\mathrm{Tie}^{2} \mathrm{Cre}^{+}$and WT as well as $\mathrm{Hifla}^{+/+} \mathrm{Tie}^{2} \mathrm{Cre}^{+}$mice at 24 hours after CLP versus baseline (Figure 3A). It then decreased and returned to basal levels in WT lungs at 96 hours after CLP, whereas it was persistently elevated in $\mathrm{Hifla}^{\mathrm{fff}} / \mathrm{Tie} 2 \mathrm{Cr} \mathrm{C}^{+}$ lungs. Hematoxylin and eosin staining revealed prominent perivascular accumulation of leukocytes in $\mathrm{Hifla}^{\mathrm{fff}} / \mathrm{Tie}_{\mathrm{e}} \mathrm{Cre}^{+}$ lungs compared with WT lungs (Figure 3B), although a similar degree of leukocyte infiltration was seen in WT and Hifla ${ }^{\text {fff }}$ / Tie $2 \mathrm{Cre}^{+}$during the injury phase (Figure 2A). Expression of proinflammatory cytokines was markedly induced in Hifla $a^{\text {fff }}$, $\mathrm{Tie} \mathrm{Cre}^{+}$lungs in contrast to WT lungs at 72 hours after CLP (Figure 3, C-F). These data suggest that endothelial HIF$1 \alpha$-mediated vascular repair is required for the resolution of lung inflammation after polymicrobial sepsis.

\section{Hematopoietic Cell-Derived HIF-1 $\alpha$ Is Not Involved in Vascular Repair}

As Tie2Cre also induces gene deletion in hematopoietic cells besides ECs ${ }^{9,31}$ (Figure 1B), it was determined whether hematopoietic HIF-1 $\alpha$ deficiency could also contribute to the recovery defects seen in Hiflatf $/ \mathrm{Tie}_{\mathrm{fCr}} \mathrm{C}^{+}$mice. Bone marrow cells, isolated from $\mathrm{Hifl} \mathrm{a}^{\mathrm{fff}} / \mathrm{Tie} 2 \mathrm{Cre}^{+}$mice, were transplanted to lethally irradiated WT mice to generate WTHifla $a^{\mathrm{BM}-1-}$ chimeric mice. As a comparison, lethally irradiated $\mathrm{Hifla} \mathrm{a}^{\mathrm{ff}} / \mathrm{Tie} 2 \mathrm{Cr}{ }^{+}$mice were reconstituted with WT bone marrow cells to generate $\mathrm{Hifla} / \mathrm{ff} / \mathrm{Tie} 2 \mathrm{Cre}^{+}-\mathrm{BM}^{+/+}$ chimeric mice. At 6 weeks after transplantation, these chimeric mice and their counterparts (WT mice reconstituted with WT bone marrow cells and Hifla $a^{f f f} / \mathrm{Tie}^{2} \mathrm{Cre}^{+}$ mice with $\mathrm{Hifl} / \mathrm{a}^{\mathrm{ff}} / \mathrm{Tie} 2 \mathrm{Cre}^{+}$bone marrow cells) were then challenged with CLP; and vascular permeability and inflammation were assessed at 72 hours after CLP challenge. EBA flux returned to the basal level in WTHifla ${ }^{\mathrm{BM}-1-}$ chimeric mice, as seen in WT mice, whereas it remained elevated in $\mathrm{Hifla} a^{f / f} / \mathrm{Tie} 2 \mathrm{Cre}^{+}-\mathrm{BM}^{+/+}$chimeric

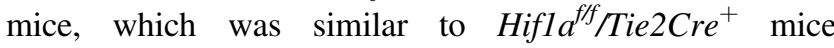
(Figure 4, A and B). Similarly, lung MPO activity was normalized in both WT and WT chimeric mice, but not in either Hifla ${ }^{f f f} / \mathrm{Tie} \mathrm{Cre}^{+}$chimeric mice or Hifl $\mathrm{a}^{\mathrm{fff}} / \mathrm{Tie} 2 \mathrm{Cr} \mathrm{C}^{+}$ mice (Figure 4C). Expression of proinflammatory cytokines was markedly increased in Hifla ${ }^{f f f} / \mathrm{Tie}_{\mathrm{i}} \mathrm{Cr}^{+}$mouse lungs compared with WT lungs regardless of the presence or absence of HIF- $1 \alpha$ in the bone marrow cells (Figure 4, $\mathrm{D}-\mathrm{G})$. These data confirmed the essential role of EC- but not hematopoietic cell-specific HIF- $1 \alpha$ in vascular repair and resolution of inflammation after polymicrobial sepsis.

\section{Endothelial HIF-1 $\alpha$ Is Required for Endothelial Regeneration during the Recovery Phase after Polymicrobial Sepsis}

The effect of endothelial HIF- $1 \alpha$ deficiency was next assessed on endothelial regeneration by quantifying the total EC numbers in $\mathrm{Hifla}^{\mathrm{fff}} / \mathrm{Tie} 2 \mathrm{Cr} e^{+}$lungs compared with WT mice. Fluorescence-activated cell sorting analysis revealed similar numbers of lung ECs (approximately 50\%) in shamoperated WT and Hifla ${ }^{f f f} / \mathrm{Tie}^{2} \mathrm{Cre}^{+}$lungs. In WT mice, lung EC percentage was returned to a level similar to shamoperated WT mice, whereas it remained markedly lower

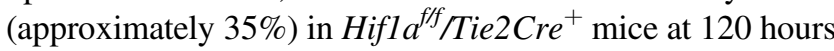
after CLP (Figure 5, A and B). These data demonstrate that HIF- $1 \alpha$ in ECs is required for endothelial regeneration after polymicrobial sepsis-induced vascular injury. Immunofluorescence staining of proliferating cells was then performed with anti-5-bromo-2-deoxyuridine antibody on lung sections to ascertain whether EC proliferation was HIF-1 $\alpha$ dependent. At 72 and 96 hours after CLP, EC proliferation was markedly induced in WT lungs, whereas these levels were inhibited in $\mathrm{Hifla}^{\mathrm{flf}} / \mathrm{Tie} \mathrm{Cr} \mathrm{Cr}^{+}$lungs (Figure 5, C and D). Expression of genes regulating cell cycle progression was markedly induced in WT, but not in Hifla ${ }^{f f f} / \mathrm{Tie}^{2} \mathrm{Cre}^{+}$, lung ECs at 96 hours after CLP (Figure 5E). Thus, endothelial HIF- $1 \alpha$ is a critical regenerative transcriptional factor mediating EC proliferation and thereby endothelial regeneration leading to vascular repair after inflammatory injury. 
A

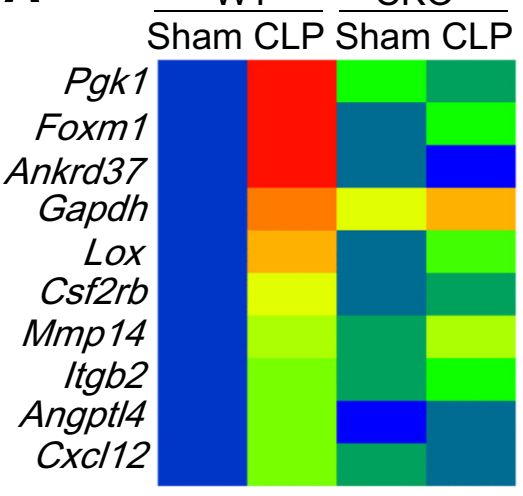

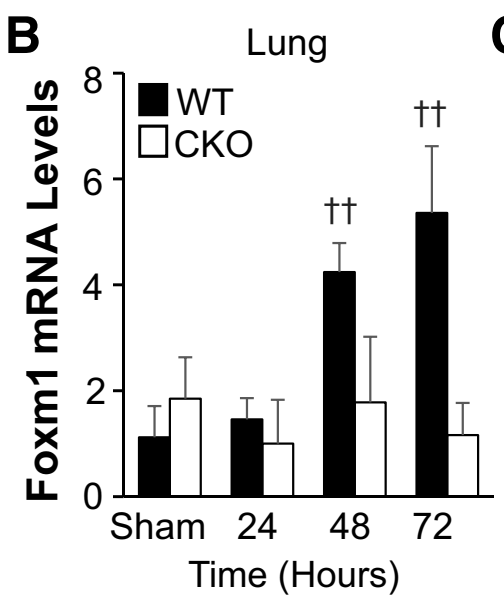

C

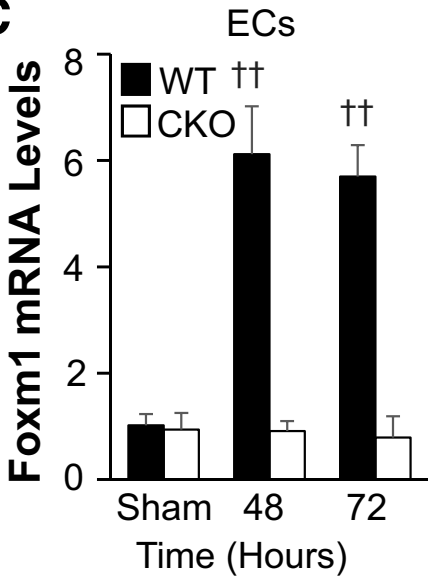

D

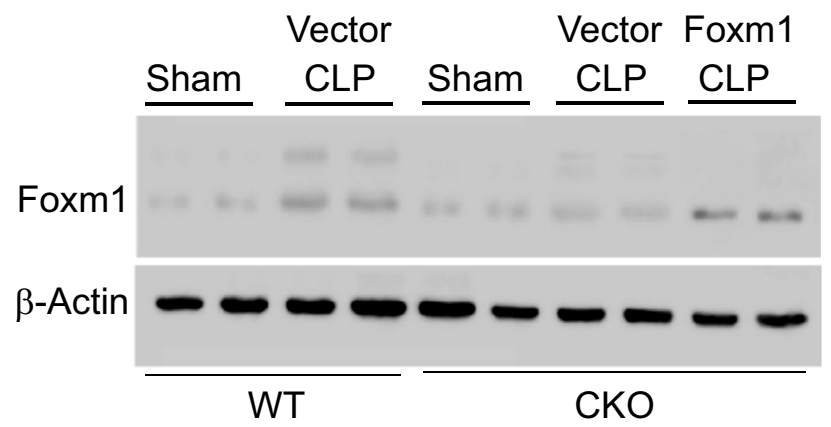

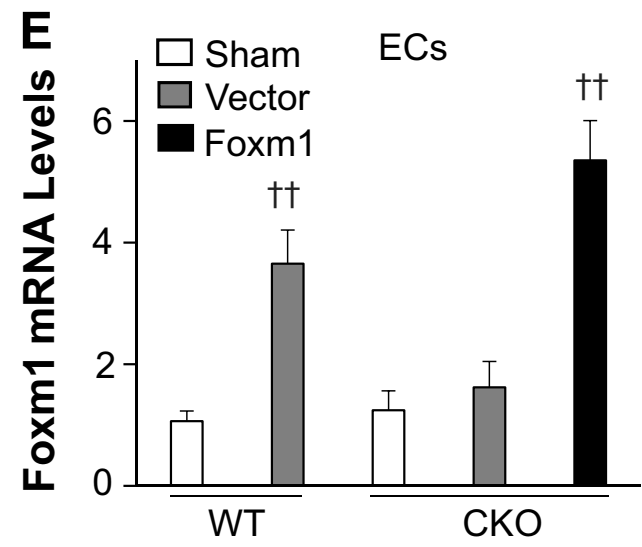
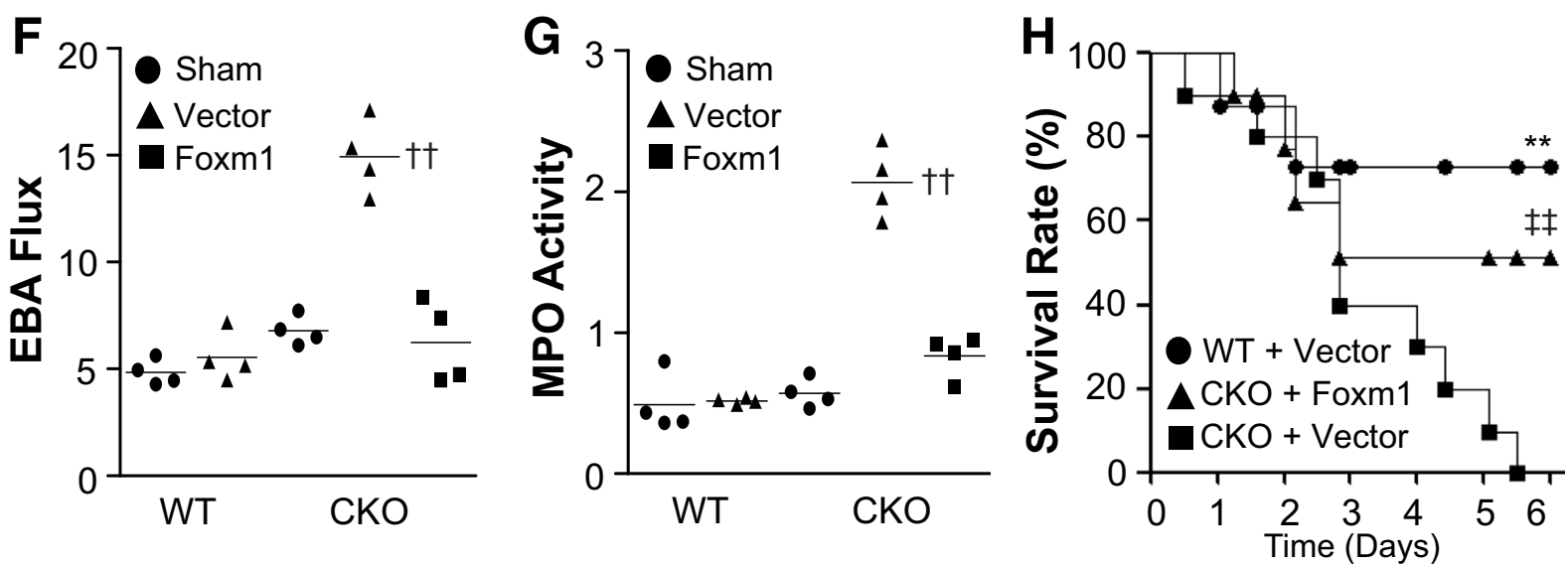

Figure 6 Restoration of endothelial forkhead box protein M1 (Foxm1) expression in Hif1 $a^{f / f} /$ Tie2Cre $^{+}$(CKO) mice rescues the defective vascular repair phenotype. A: Heat map of RNA-sequencing (RNA-seq) analysis of gene expression in wild-type (WT) and Hif1 f/f $/ \mathrm{Tie}^{\mathrm{CCre}} \mathrm{C}^{+}$mouse lungs at 72 hours after cecal ligation and puncture (CLP) compared with sham. RNA samples from three mouse lungs were combined for RNA-seq analysis in each group. B and C: Real-time quantitative RT-PCR (RT-qPCR) analysis of Foxm1 expression in WT and Hif1 $a^{f / f} /$ Tie2Cre $^{+}$mouse lung tissues at various times and freshly isolated lung endothelial cells (ECS) after CLP. D: Representative Western blot analysis showing restored Foxm1 protein expression in Foxm1 plasmid DNA-transduced Hif1 $a^{f /}$ $f / T_{i e 2} \mathrm{Cre}^{+}$mouse lungs. At 12 hours after CLP challenge, a mixture of liposome/plasmid DNA expressing Foxm1 under the control of the CDH5 promoter (Foxm1) or empty vector (Vector) was administered intravenously to Hif1 $a^{f / f} / \mathrm{Tie}_{\mathrm{C}} \mathrm{Cre}^{+}$mice. WT mice were also administered with Vector as controls. At 72 hours after CLP, lung tissues were collected for Western blot analysis with anti-Foxm1 and anti- $\beta$-actin (loading control). E: RT-qPCR analysis of Foxm1 expression in ECs freshly isolated from lungs of mice treated as described in D. F: Pulmonary transvascular Evans Blue Dye-conjugated albumin (EBA) flux measurement demonstrating normalized vascular repair of $\mathrm{Hifla}_{\mathrm{a}}^{\mathrm{f} / \mathrm{f}} / \mathrm{Tie} 2 \mathrm{Cre} \mathrm{r}^{+}$mice transduced with Foxm1 plasmid DNA at 72 hours after CLP. G: Myeloperoxidase (MPO) assay demonstrating normalized resolution of lung inflammation in $\mathrm{Hif1} \mathrm{a}^{\mathrm{f} / \mathrm{f}} / \mathrm{Tie} 2 \mathrm{Cre} \mathrm{e}^{+}$mice transduced with Foxm1 plasmid DNA at 72 hours after CLP. H: Restored Foxm1 expression in ECs of $\mathrm{Hifl}^{\mathrm{f} / f} / \mathrm{Tie}_{2} \mathrm{Cre}^{+}$mouse lungs promotes survival. At 12 hours after CLP challenge, a mixture of liposome/plasmid DNA was administered to WT or Hif1 $a^{f / f} /$ Tie2Cre $\mathrm{Cr}^{+}$mice. Survival rate was monitored for 6 days. Data are expressed as means \pm SD (B, C, and E) or means (F and $\mathbf{G}) . n=5$ per group (B); $n=4$ per group $(\mathbf{C}$ and $\mathbf{E}) .{ }^{*} P<0.01$ versus $C K 0+$ Vector; ${ }^{\dagger \dagger} P<0.01$ versus WT-sham (one-way analysis of variance); ${ }^{\ddagger \ddagger} P<0.01$ versus CKO + Vector (Mantel-Cox test). 
A

CD31/vWF/BrdU/DAPI
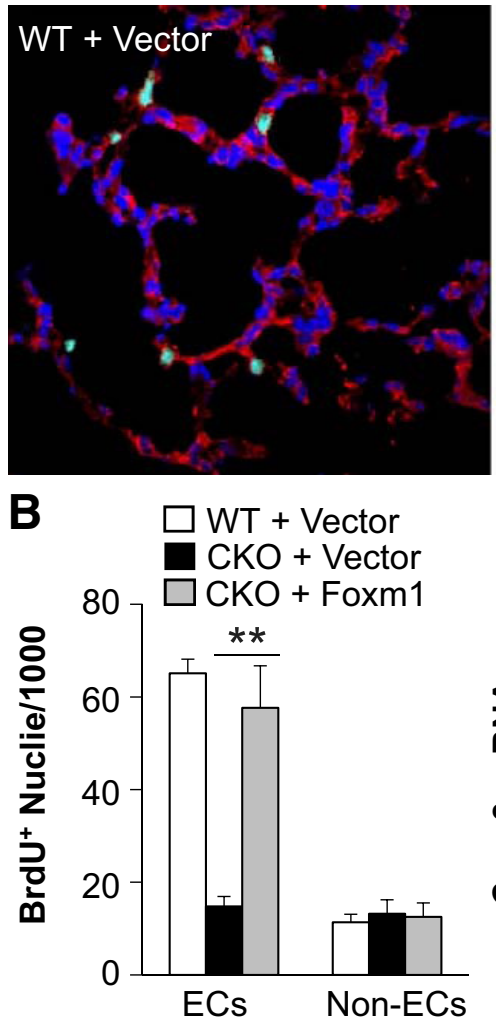

CD31/vWF/BrdU/DAPI
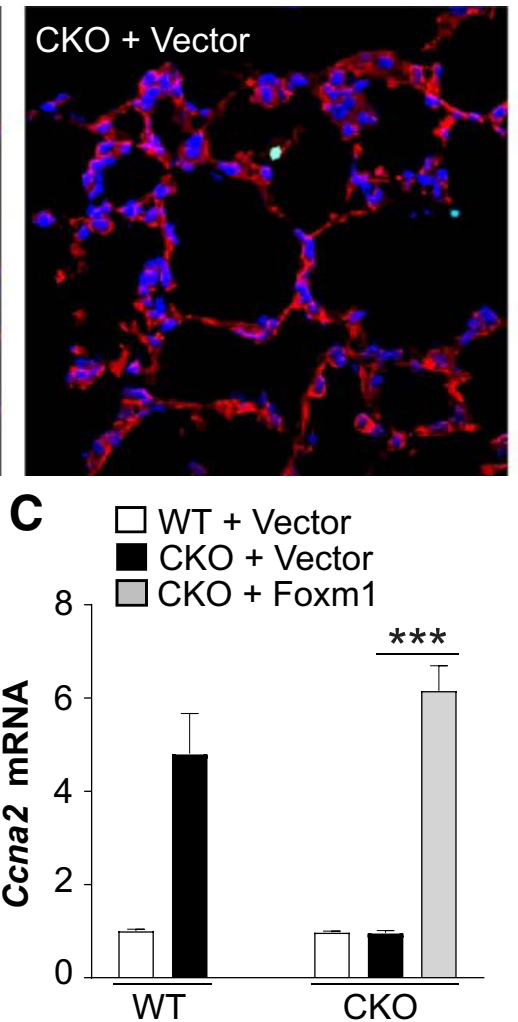

CD31/vWF/BrdU/DAPI
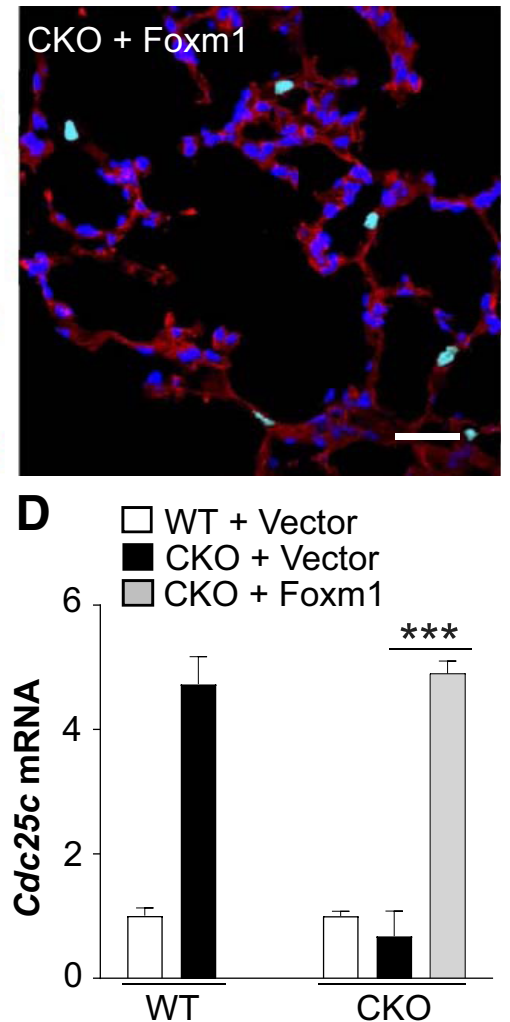

Figure 7 Restoration of endothelial forkhead box protein M1 (Foxm1) expression in Hif1 $a^{f / f} /$ Tie2Cre (CK0) mice normalizes endothelial cell (EC) proliferation. A: Representative micrographs of immunostaining of lung sections. At 12 hours after cecal ligation and puncture (CLP), Hif1 $a^{f / f} / T_{i e 2 C r e}^{+}$mice were administered intravenously with liposome/Foxm1 plasmid DNA (CKO + Foxm1) or vector (CKO + Vector). Wild-type (WT) mice were also administered with vector. At 72 hours after CLP, mouse lungs were collected. Cryosections were immunostained with anti-5-bromo-2-deoxyuridine (BrdU) (green) and antiCD31/anti-von Willebrand factor (vWF; red) antibodies. Nuclei were counterstained with DAPI (blue). B: Quantification of BrdU-positive ECs and non-ECs. C and D: Real-time quantitative RT-PCR analysis of expression of genes regulating cell cycle progression. Data are expressed as means \pm SD (B-D). ${ }^{* *} P<0.01$, $* * * P<0.001$ (t-test). Scale bar $=50 \mu \mathrm{m}(\mathbf{A})$.

\section{Endothelial HIF-1 $\alpha$-Mediated Vascular Repair Is Foxm1 Dependent}

To define the downstream target(s) of HIF- $1 \alpha$ responsible for endothelial regeneration and vascular repair, RNAsequencing analysis was first performed. Among the 80 HIF-1 $\alpha$ target genes, 10 of them had more than a twofold increase in WT lungs at 72 hours after CLP compared with WT-sham but no marked changes in $\mathrm{Hifla}^{\text {fff }} / \mathrm{Tie}_{\mathrm{T}} \mathrm{Cre}^{+}$lungs

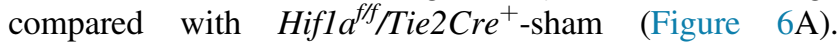
Expression of vascular endothelial growth factor was not induced (data not shown). As Foxm1 is on the top list and is involved in EC proliferation and vascular repair, ${ }^{9,13}$ it was next determined whether HIF-1 $\alpha$ regulates Foxm1 expression in ECs. In mouse lung samples, CLP-induced increases in Foxm1 expression were confirmed in WT mice and shown to be HIF-1 $\alpha$ dependent (Figure $6 \mathrm{~B}$ ). Using freshly isolated ECs, Foxm1 was found to be predominantly induced in lung ECs of WT, but not $\mathrm{Hifla}^{\mathrm{fff}} / \mathrm{Tie}^{\mathrm{C}} \mathrm{Cre}^{+}$, mice (Figure 6C). Putative HIF-response elements were identified in mouse Foxm1 promoter (Supplemental Figure S2).
A cationic liposome-mediated in vivo gene transduction approach $^{13,33,34}$ was next used to determine whether inhibited Foxm1 expression is responsible for the defective endothelial proliferation and vascular repair seen in Hifla ${ }^{\text {fff }} / \mathrm{Tie}_{\mathrm{C}} \mathrm{Cre}^{+}$mice. A mixture of liposome and plasmid DNA expressing Foxm1 under the control of human $\mathrm{CDH} 5$ promoter $\left(\mathrm{EC}\right.$ specific) ${ }^{13}$ was administered intravenously to $\mathrm{Hifla}^{\mathrm{fff}} / \mathrm{Tie}_{\mathrm{C}} \mathrm{Cre}^{+}$mice at 12 hours after CLP. Control vector-loaded liposomes were also delivered to WT mice and Hifla ${ }^{f f} / \mathrm{Tie} 2 \mathrm{Cre}^{+}$mice. Foxm1 protein expression was induced in WT mouse lungs at 72 hours after CLP but not in Hifl ${ }^{f f f} / \mathrm{Tie} 2 \mathrm{Cre}^{+}$lungs transduced with vector plasmid (Figure 6D). Transduction of Foxm1 plasmid DNA resulted in increased expression of Foxm1 in $\mathrm{Hifla}^{\mathrm{fff}} / \mathrm{Tie}_{\mathrm{C}} \mathrm{Cre}^{+}$ lungs. Real-time quantitative RT-PCR analysis also demonstrated normalized Foxm1 expression in lung ECs (Figure 6E) of Foxm1 plasmid DNA-transduced Hifla ${ }^{f f}$ / $\mathrm{Tie}^{2} \mathrm{Cre}^{+}$mice. Furthermore, endothelial expression of Foxm1 in Hifla fff $_{\text {Tie } 2 \mathrm{Cre}^{+}}$mouse lungs resulted in normalization of vascular repair at 72 hours after CLP (Figure 6F). MPO activity in Foxm1 plasmid-transduced 


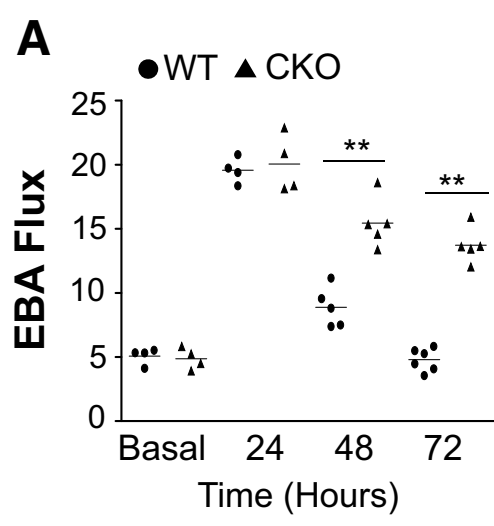

D

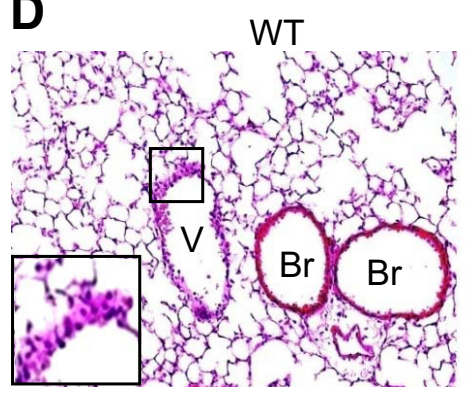

$\mathbf{F}$

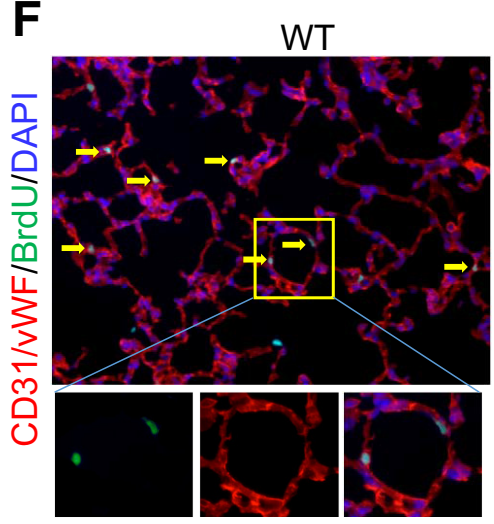

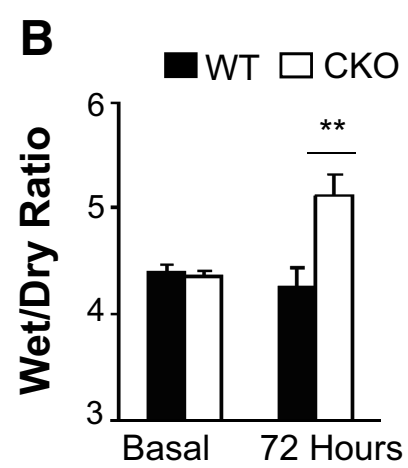
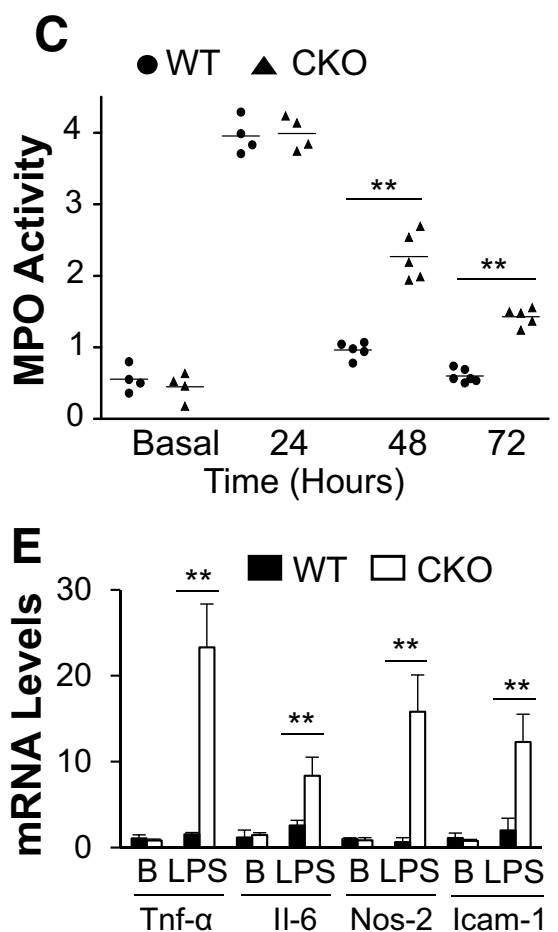

G

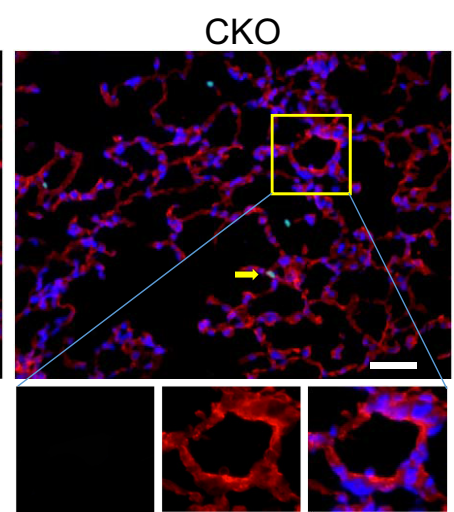

Figure 8 Endothelial regeneration and vascular repair after endotoxemia-induced injury is also HIF-1 $\alpha$ dependent. A: Pulmonary transvascular Evans Blue Dye-conjugated albumin (EBA) flux assay demonstrating defective vascular repair in Hif1 $1 a^{f / f} / T_{i e 2 C r e}^{+}$(CKO) mouse lungs after lipopolysaccharide (LPS) challenge $\left(2.5 \mathrm{mg} / \mathrm{kg}\right.$, intraperitoneally). B: Lung wet/dry weight ratio analysis revealing lung edema in Hif1 f/f $/$ Tie2Cre ${ }^{+}$mice at 72 hours after LPS.C: Time course of lung myeloperoxidase (MP0) activity after LPS challenge. D: Representative micrographs of hematoxylin and eosin staining of lung sections showing perivascular leukocyte sequestration in $\mathrm{Hif1} \mathrm{a}^{f / f} / \mathrm{Tie} 2 \mathrm{Cr} \mathrm{e}^{+}$mouse lungs at 72 hours after LPS. The boxed areas are shown at higher magnification in the insets

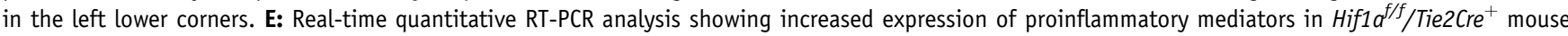
lungs at 72 hours after LPS. F: Representative micrographs showing endothelial cell (EC) proliferation. Cryosections of lungs ( $5 \mu \mathrm{m}$ thick) collected at 72 hours after LPS were immunostained with anti-5-bromo-2-deoxyuridine (BrdU) antibody to identify proliferating cells (green) and with anti-CD31/von Willebrand factor (VWF) antibodies to identify ECs (red). Arrows indicate proliferating Ecs. The boxed areas in the top panels are shown at higher magnification in the three bottom panels. G: Quantification of cell proliferation in mouse lungs. Three consecutive cryosections from each mouse lung were examined, and the average number of $\mathrm{BrdU}^{+}$nuclei was used for each mouse. Data are expressed as means (A and $\mathbf{C}$ ) or means $\pm \mathrm{SD}(\mathbf{B}, \mathbf{E}$, and $\mathbf{G}) . n=5$ mice per group (B); $n=4$ (E and $\mathbf{G}) .{ }^{*} P<0.01$ (t-test). Scale bars $=50 \mu \mathrm{m}$ ( $\mathbf{D}$ and $\left.\mathbf{F}\right)$. B, basal; Br, bronchiole; Icam-1, intercellular adhesion molecule 1; Nos-2, inducible nitric oxide synthase; Tnf- $\alpha$, tumor necrosis factor $-\alpha$; V, vessel; WT, wild type.

Hifla ${ }^{f f} / \mathrm{Tie} 2 \mathrm{Cre}^{+}$lungs at 72 hours after CLP was also returned to the basal levels seen in vector DNA-transduced WT mice (Figure 6G). Accordingly, endothelial expression of Foxm1 resulted in a marked increase of survival of Foxm1 plasmid DNA-transduced $\mathrm{Hifla}^{\mathrm{ff}} / \mathrm{Tie} 2 \mathrm{Cre}^{+}$mice (Figure 6H).

Furthermore, the impaired pulmonary vascular EC proliferation seen in Hifl $\mathrm{a}^{\mathrm{fff}} / \mathrm{Tie} 2 \mathrm{Cr} \mathrm{C}^{+}$mice was rescued by liposomal delivery of Foxm1 plasmid DNA (Figure 7, A and B). These Foxm1-dependent restorations in EC proliferation were accompanied by Foxm1-dependent restorations in the expression of genes regulating cell cycle progression (Figure 7, C and D). Together, these data demonstrate that Foxm1 is regulated by HIF- $1 \alpha$ in lung ECs that are responsible for endothelial regeneration and vascular repair after polymicrobial sepsis. 
Lung Vascular Repair after Endotoxemia Is Also HIF-1 $\alpha$ Dependent

To confirm the role of endothelial HIF- $1 \alpha$ in vascular repair in endotoxemia, mice were challenged with LPS. As seen in the context of polymicrobial sepsis described above, pulmonary vascular permeability in $\mathrm{Hifla} / \mathrm{ff} / \mathrm{Tie} 2 \mathrm{Cre}^{+}$mice at 24 hours after LPS was increased by a similar level in WT mice (Figure 8A). During the recovery phase, EBA flux returned to basal levels at 72 hours after LPS in WT, whereas it remained elevated in $\mathrm{Hifla}^{f f f} / \mathrm{Tie}_{\mathrm{C}} \mathrm{Cre}^{+}$, mouse lungs, indicating impaired vascular repair. $\mathrm{Hifla}^{+/+} /$ Tie2Cre mice exhibited similar injury and repair responses to LPS challenge as seen in WT (Hifl $a^{\text {fff }}$ ) mice (Supplemental Figure S3), indicating Cre expression per se does not affect lung injury and repair. Hifla $a^{f f} /$ Tie $\mathrm{Cre}^{+}$ lungs exhibited pulmonary edema at 72 hours after LPS in contrast to WT mice (Figure 8B). Hifla $a^{\mathrm{flf}} / \mathrm{Tie}_{\mathrm{e}} \mathrm{Cre}^{+}$mice also exhibited defective resolution of inflammation, evident by the persistent increase in lung MPO activity during the recovery phase, and perivascular infiltration of neutrophils, as well as increased expression of proinflammatory cytokines at 72 hours after LPS (Figure 8, C-E). Anti-5bromo-2-deoxyuridine immunostaining also revealed defective EC proliferation in $\mathrm{Hifla}^{\mathrm{fff}} / \mathrm{Tie} 2 \mathrm{Cre}^{+}$lungs after LPS challenge (Figure 8, F and G).

\section{Discussion}

In this study, we have demonstrated that endothelial HIF-1 $\alpha$ plays a prerequisite role in mediating vascular repair and resolution of inflammatory lung injury after sepsis challenge. Mice with endothelial-specific Hifla deletion exhibited defective endothelial proliferation and vascular repair and impaired resolution of inflammation, resulting in increased mortality. Restored expression of Foxm1 in lung ECs of $\mathrm{Hifla}^{\mathrm{fff}} / \mathrm{Tie} 2 \mathrm{Cre}^{+}$mice normalized endothelial proliferation and vascular repair and improved survival. Our study provides evidence that the endothelial HIF$1 \alpha$-Foxm 1 pathway is a strong candidate for therapeutic targeting in the treatment of sepsis and ARDS.

Several studies have identified endothelial barrier dysfunction as the major contributor to lung injury and poor prognostic outcomes of sepsis. ${ }^{9-13,35,36}$ The disrupted endothelial barrier and the subsequent microvascular leakage may result from pulmonary EC loss. A marked increase of EC apoptosis was observed after sepsis challenge. Consistent with our observation, several studies have shown that the total number of pulmonary vascular ECs transiently decreased in mice after sepsis. ${ }^{37-40}$ However, $\mathrm{Hifla}^{\mathrm{fff}} / \mathrm{Tie}_{\mathrm{COre}} \mathrm{Cr}^{+}$mice and WT mice exhibited a similar degree of lung EC apoptosis. Accordingly, lung vascular injury and inflammation at the initial injury phase after sepsis challenge are similar between $\mathrm{Hifl} a^{\mathrm{fff}} / \mathrm{Tie}_{\mathrm{e}} \mathrm{Cre}^{+}$mice and WT mice, demonstrating that endothelial HIF- $1 \alpha$ is not involved in the initial inflammatory responses to sepsis challenge.

ECs are normally quiescent, with a low turnover rate. In response to injury, expression of some transcriptional factors is induced to activate EC proliferation. It has been shown that the forkhead transcriptional factor Foxm1 is markedly induced in ECs in the recovery phase but not in the injury phase after LPS challenge. ${ }^{9}$ Genetic deletion of Foxm 1 in ECs impairs endothelial proliferation and vascular repair. Overexpression of Foxm1 augments EC proliferation and promotes resolution of inflammation. ${ }^{41} \mathrm{~A}$ previous study shows that endothelial NF- $\kappa \mathrm{B}$ is also involved in EC proliferation and vascular repair in mouse lungs after endotoxemia. ${ }^{42}$ Herein, we show that HIF- $1 \alpha$ is rapidly induced and stabilized in lung ECs in the injury phase after sepsis challenge. Genetic deletion of Hifla leads to inhibited EC proliferation and impaired vascular repair in the repair phase. Although there was a similar degree of lung vascular injury and inflammation in the injury phase, $\mathrm{Hifla}^{\text {fff }} / \mathrm{Tie}_{\mathrm{Cr}} \mathrm{Cr}^{+}$mice exhibited persistent injury and inflammation and increased mortality compared with WT mice. Thus, HIF- $1 \alpha$ is a rapidly induced transcriptional factor responsible for endothelial regeneration and vascular repair after sepsis-induced vascular injury.

HIF- $\alpha$ protein levels are generally regulated by post-translational modification through hydroxylasemediated hydroxylation and subsequent proteasomal degradation. ${ }^{23-25}$ Under hypoxia condition and inflammation, which induces tissue hypoxia, HIF- $\alpha$ is stabilized and activated. Herein, a rapid induction of HIF- $1 \alpha$ mRNA levels was observed as early as 2 hours and that peaked at 8 hours after sepsis. However, the HIF- $2 \alpha$ mRNA level was, in contrast, markedly decreased at the same time. Accordingly, a greater than eightfold increase of HIF- $1 \alpha$ protein levels was observed in WT lungs at 8 hours after CLP compared with sham, whereas HIF- $2 \alpha$ protein levels were only increased twofold. These data show that HIF- $\alpha$ subunits are regulated in both transcriptional and post-transcriptional levels under the inflammatory condition. Previous studies have also demonstrated that HIF- $1 \alpha$ is regulated at the transcriptional level. NF- $\kappa \mathrm{B}$ is a critical mediator of HIF- $1 \alpha$ transcriptional regulation in inflammatory conditions. ${ }^{43}$ In macrophages, LPS also up-regulates HIF- $1 \alpha$ mRNA levels in a toll-like receptor 4-dependent manner. ${ }^{44}$ Thus, future study is warranted to determine whether HIF- $1 \alpha$ mRNA up-regulation is mediated by NF- $\kappa \mathrm{B}$ activation in a toll-like receptor 4 -dependent manner after sepsis challenge and to understand the mechanisms of differential regulation of HIF- $1 \alpha$ and HIF- $2 \alpha$ transcription in response to sepsis challenge. Our study demonstrated that endothelial HIF- $1 \alpha$ plays an important role in mediating vascular repair during the recovery phase. However, it remains unclear whether induced HIF- $1 \alpha$ mRNA expression is required for the reparative effect.

RNA-sequencing analysis and subsequent real-time quantitative RT-PCR analysis demonstrated a marked induction of Foxm1 expression in WT mouse lungs after CLP 
challenge, which was inhibited in $\mathrm{Hifl} \mathrm{a}^{\mathrm{fff}} / \mathrm{Tie} 2 \mathrm{Cr} e^{+}$lungs. Our promoter analysis has identified seven putative hypoxia-response elements in the $3.5-\mathrm{Kb}$ mouse Foxm 1 promoter, indicating HIF- $\alpha$ may directly bind to these elements to up-regulate Foxm1 expression. Because only HIF- $1 \alpha$ protein level is markedly increased after sepsis challenge, it is our expectation that these hypoxia-response elements will be predominantly occupied by HIF- $1 \alpha$ but not HIF- $2 \alpha$, leading to HIF- $1 \alpha$-dependent induction of Foxm1 expression. These data further show that HIF$1 \alpha$-dependent Foxm1 expression in ECs is critical for activating the intrinsic endothelial regeneration and vascular repair program. Endothelial-specific expression of Foxm1 in Hifl ${ }^{\mathrm{fff}} / \mathrm{Tie} 2 \mathrm{Cre}^{+}$mouse lungs was sufficient to activate vascular repair and promote survival. Collectively, these data demonstrate that endothelial HIF- $1 \alpha /$ Foxm 1 signaling is a crucial intrinsic regenerative pathway for vascular repair after inflammatory injury. This study demonstrates an indirect anti-inflammatory role of HIF- $1 \alpha$ through Foxm1dependent vascular repair and resultant resolution of inflammation. Previous studies also show an antiinflammatory role of HIF- $1 \alpha$ through induction of anti-inflammatory signaling molecules, such as adenosine or netrin- $1 .{ }^{45,46}$ However, HIF- $1 \alpha$ is also an important mediator of hypoxia-induced inflammation. ${ }^{47}$ Thus, under different pathologic conditions, HIF- $1 \alpha$ signaling can lead to proinflammation or anti-inflammation through direct or indirect pathways.

After loss of ECs, regeneration of the endothelial monolayer is possible from multiple sources, including resident EC proliferation, recruitment of circulating ECs or endothelial progenitor cells, and contribution of bone marrow-derived progenitor cells. Published studies have shown that proliferative capillary ECs, not the bone marrow cells, mediate vascular repair after hyperoxia-induced endothelial injury. ${ }^{48}$ Mao et $\mathrm{al}^{42}$ also show that resident ECs are the major contributor to repair, whereas bone marrow-derived endothelial precursor cells are a complementary source of new ECs in endothelial barrier restoration after LPS challenge. Herein, we show that $\mathrm{Hifl} \mathrm{a}^{\mathrm{ff}} / \mathrm{Tie} 2 \mathrm{Cre}$ mice exhibited defective vascular repair. Given that Tie2Cre also induces gene deletion in bone marrow cells besides ECs, ${ }^{9,31}$ it is possible that bone marrow cell HIF- $1 \alpha$ also contributes to vascular repair. However, our bone marrow transplantation study excludes the possibility and demonstrates that HIF- $1 \alpha$ expressed in bone marrow cells is not involved in vascular repair, further supporting our concept that endothelial HIF- $1 \alpha$ expression is responsible for resident EC proliferation and subsequent vascular repair. Using genetic lineage tracing and parabiosis, it has been shown that resident EC proliferation plays a dominant role in endothelial regeneration and vascular repair in large vessels after injury. ${ }^{49}$ Thus, it is likely that resident EC proliferation is an intrinsic regenerative mechanism mediating endothelial regeneration and vascular repair in the systemic vasculature as well as in the pulmonary vasculature. Indeed, our published study demonstrates that $110 \gamma$ phosphatidylinositol 3-kinase signaling is responsible for vascular repair of both the pulmonary and systemic vasculatures. ${ }^{13}$

HIF- $1 \alpha$ signaling is involved in the pathogenesis of lung injury. ${ }^{50}$ In the ventilator-induced lung injury model, HIF$1 \alpha$ signaling in alveolar epithelial cells has been reported to play a protective role, whereas endothelial HIF- $1 \alpha$ is not involved in the protective effect. ${ }^{51}$ Genetic deletion of endothelial HIF-1 $\alpha$ has negligible effects on ventilatorinduced lung injury and mortality, which seems to contrast our observation in the sepsis-induced lung injury model. The discrepancy is likely ascribed to the differences of the lung injury models. Ventilator-induced injury is more of an epithelial injury model, whereas sepsis-induced inflammatory lung injury is more of an endothelial injury model. We and others observed a marked increase of endothelial apoptosis after sepsis challenge. In addition, our data show that endothelial HIF- $1 \alpha$ is not involved in the injury response after sepsis challenge. Hifl $a^{f f} /$ Tie $2 \mathrm{Cre}$ mice exhibit a similar degree of lung injury during the injury phase, which is consistent with the observation in the acute phase ( 3 hours) of ventilator-induced lung injury. ${ }^{51}$ It is unclear if endothelial HIF-1 $\alpha$ is involved in repair and recovery in a sublethal ventilator-induced lung injury model, as seen in our sepsis model. In another epithelial injury model induced by i.t. instillation of LPS or hydrochloric acid, epithelial HIF-1 $\alpha$ is shown to promote type II epithelial cell proliferation and spreading for epithelium repair. ${ }^{52}$ In response to endotoxemia, myeloid HIF-1 $\alpha$ plays a detrimental role. Deletion of Hifla in myeloid cells is protective against LPS-induced mortality and septic shock. ${ }^{44}$ These studies demonstrate that HIF- $1 \alpha$ expression in different cell types functions differently in different pathologic conditions.

Although they share many common signaling pathways and possess similar regulatory effects in physiological and pathologic conditions, the two major HIF- $\alpha$ isoforms (HIF$1 \alpha$ and HIF-2 $\alpha$ ) in ECs may exert differential effects. Endothelial HIF- $2 \alpha$, not HIF- $1 \alpha$, mediates renal protection and recovery after ischemic kidney injury through increased inflammatory cell infiltration. ${ }^{53}$ In mouse mammary cancer models, loss of HIF- $1 \alpha$ in ECs reduces nitric oxide synthesis and restricts tumor cell metastasis, whereas loss of endothelial HIF-2 $\alpha$ has the opposite effect. ${ }^{54}$ Deletion of Hif $2 a$, but not Hifla, in cardiac myocytes deteriorates myocardial ischemia-reperfusion injury. ${ }^{55}$ Endothelial HIF-2 $\alpha$, but not HIF- $1 \alpha$, contributes to the pathogenesis of pulmonary artery hypertension, ${ }^{56,57}$ although HIF-1 $\alpha$ expression in smooth muscle cells is involved in pulmonary vascular remodeling and development of pulmonary hypertension. ${ }^{58}$ Hypoxiainduced stabilization of the endothelial barrier integrity is mediated by endothelial HIF- $2 \alpha .{ }^{26}$ Under basal conditions, HIF- $2 \alpha$ is the predominant isoform expressed in ECs, which mediates vascular endothelial-phosphotyrosine phosphatase expression, leading to enhanced dephosphorylation of VEcadherin, and thereby promotes endothelial adherens 
junction integrity and endothelial barrier function. ECspecific loss of HIF- $2 \alpha$ exaggerates LPS-induced lung injury in the injury phase through disruption of the endothelial barrier. However, the study fails to examine the role of endothelial HIF- $2 \alpha$ in vascular repair and resolution of inflammation during the recovery phase after LPS challenge. ${ }^{26}$ In contrast to HIF- $1 \alpha$, HIF- $2 \alpha$ mRNA expression in WT mouse lungs is acutely decreased after CLP challenge, indicating that HIF- $2 \alpha$ is not involved in vascular repair during the recovery phase. Nevertheless, future study is warranted to investigate the role of endothelial HIF- $2 \alpha$ in regulating Foxm1 expression and endothelial proliferation and vascular repair during the recovery phase after sepsis challenge. Given that vascular repair requires endothelial proliferation and recovery of endothelial barrier function, it is possible that endothelial HIF- $1 \alpha$ and HIF- $2 \alpha$ synergistically work to promote endothelial proliferation and reannealing of endothelial adherens junctions and thereby vascular repair.

In summary, our studies demonstrate that endothelial HIF- $1 \alpha$ is a critical transcription factor mediating the intrinsic endothelial regenerative program for vascular repair and resolution of inflammatory injury through endothelial expression of Foxm1. Thus, therapeutic activation of HIF- $1 \alpha /$ Foxm 1 signaling, especially in ECs, may be an effective approach for the prevention and treatment of sepsis, ARDS, and other inflammatory vascular diseases. Given that HIF prolyl hydroxylase inhibitors, such as FG4592 and GSK1278863, have been in phase 3 clinical trials of patients with chronic kidney disease in the United States, ${ }^{59,60}$ these agents may have the potential to treat sepsis and ARDS via activation of HIF- $1 \alpha$-dependent endothelial regeneration and vascular repair.

\section{Supplemental Data}

Supplemental material for this article can be found at http://doi.org/10.1016/j.ajpath.2019.04.014.

\section{References}

1. Cines DB, Pollak ES, Buck CA, Loscalzo J, Zimmerman GA, McEver RP, Pober JS, Wick TM, Konkle BA, Schwartz BS, Barnathan ES, McCrae KR, Hug BA, Schmidt AM, Stern DM: Endothelial cells in physiology and in the pathophysiology of vascular disorders. Blood 1998, 91:3527-3561

2. Deanfield JE, Halcox JP, Rabelink TJ: Endothelial function and dysfunction: testing and clinical relevance. Circulation 2007, 115: 1285-1295

3. Aird WC: Phenotypic heterogeneity of the endothelium, I: structure, function, and mechanisms. Circ Res 2007, 100:158-173

4. Libby P, Ridker PM, Maseri A: Inflammation and atherosclerosis Circulation 2002, 105:1135-1143

5. Austin GE, Ratliff NB, Hollman J, Tabei S, Phillips DF: Intimal proliferation of smooth muscle cells as an explanation for recurrent coronary artery stenosis after percutaneous transluminal coronary angioplasty. J Am Coll Cardiol 1985, 6:369-375
6. Schwartz RS, Holmes DR Jr, Topol EJ: The restenosis paradigm revisited: an alternative proposal for cellular mechanisms. J Am Coll Cardiol 1992, 20:1284-1293

7. Aird WC: The role of the endothelium in severe sepsis and multiple organ dysfunction syndrome. Blood 2003, 101:3765-3777

8. Goldenberg NM, Steinberg BE, Slutsky AS, Lee WL: Broken barriers: a new take on sepsis pathogenesis. Sci Transl Med 2011, 3: $88 \mathrm{ps} 25$

9. Zhao YY, Gao XP, Zhao YD, Mirza MK, Frey RS, Kalinichenko VV, Wang IC, Costa RH, Malik AB: Endothelial cell-restricted disruption of FoxM1 impairs endothelial repair following LPS-induced vascular injury. J Clin Invest 2006, 116:2333-2343

10. De Backer D, Creteur J, Preiser JC, Dubois MJ, Vincent JL: Microvascular blood flow is altered in patients with sepsis. Am J Respir Crit Care Med 2002, 166:98-104

11. Trzeciak S, Dellinger RP, Parrillo JE, Guglielmi M, Bajaj J, Abate NL, Arnold RC, Colilla S, Zanotti S, Hollenberg SM; Microcirculatory Alterations in Resuscitation and Shock Investigators: Early microcirculatory perfusion derangements in patients with severe sepsis and septic shock: relationship to hemodynamics, oxygen transport, and survival. Ann Emerg Med 2007, 49:88-98. $98 \mathrm{e} 1-98 \mathrm{e} 2$

12. Sakr Y, Dubois MJ, De Backer D, Creteur J, Vincent JL: Persistent microcirculatory alterations are associated with organ failure and death in patients with septic shock. Crit Care Med 2004, 32: $1825-1831$

13. Huang X, Dai Z, Cai L, Sun K, Cho J, Albertine KH, Malik AB, Schraufnagel DE, Zhao YY: Endothelial p110gammaPI3K mediates endothelial regeneration and vascular repair after inflammatory vascular injury. Circulation 2016, 133:1093-1103

14. Laffey JG, Kavanagh BP: Fifty years of research in ARDS: insight into acute respiratory distress syndrome: from models to patients. Am J Respir Crit Care Med 2017, 196:18-28

15. Minamino T, Komuro I: Regeneration of the endothelium as a novel therapeutic strategy for acute lung injury. J Clin Invest 2006, 116 : 2316-2319

16. Rubenfeld GD, Caldwell E, Peabody E, Weaver J, Martin DP, Neff M, Stern EJ, Hudson LD: Incidence and outcomes of acute lung injury. N Engl J Med 2005, 353:1685-1693

17. Matthay MA, Ware LB, Zimmerman GA: The acute respiratory distress syndrome. J Clin Invest 2012, 122:2731-2740

18. Fan E, Brodie D, Slutsky AS: Acute respiratory distress syndrome: advances in diagnosis and treatment. JAMA 2018, 319:698-710

19. Wang GL, Jiang BH, Rue EA, Semenza GL: Hypoxia-inducible factor 1 is a basic-helix-loop-helix-PAS heterodimer regulated by cellular O2 tension. Proc Natl Acad Sci U S A 1995, 92: $5510-5514$

20. Majmundar AJ, Wong WHJ, Simon MC: Hypoxia-inducible factors and the response to hypoxic stress. Mol Cell 2010, 40:294-309

21. Semenza GL: Oxygen sensing, homeostasis, and disease. N Engl J Med 2011, 365:537-547

22. Semenza GL: Oxygen sensing, hypoxia-inducible factors, and disease pathophysiology. Annu Rev Pathol 2014, 9:47-71

23. Palazon A, Goldrath AW, Nizet V, Johnson RS: HIF transcription factors, inflammation, and immunity. Immunity 2014, 41:518-528

24. Kaelin WG Jr, Ratcliffe PJ: Oxygen sensing by metazoans: the central role of the HIF hydroxylase pathway. Mol Cell 2008, 30:393-402

25. Minamishima YA, Kaelin WG Jr: Reactivation of hepatic EPO synthesis in mice after PHD loss. Science 2010, 329:407

26. Gong H, Rehman J, Tang H, Wary K, Mittal M, Chaturvedi P, Zhao YY, Komarova YA, Vogel SM, Malik AB: HIF2alpha signaling inhibits adherens junctional disruption in acute lung injury. J Clin Invest 2015, 125:652-664

27. Committee for the Update of the Guide for the Care and Use of Laboratory Animals; National Research Council: Guide for the Care and Use of Laboratory Animals: Eighth Edition. Washington, DC, National Academies Press, 2011 
28. Wichterman KA, Baue AE, Chaudry IH: Sepsis and septic shock: a review of laboratory models and a proposal. J Surg Res 1980, 29:189-201

29. Buras JA, Holzmann B, Sitkovsky M: Animal models of sepsis: setting the stage. Nat Rev Drug Discov 2005, 4:854-865

30. Rittirsch D, Huber-Lang MS, Flierl MA, Ward PA: Immunodesign of experimental sepsis by cecal ligation and puncture. Nat Protoc 2009, 4:31-36

31. Kisanuki YY, Hammer RE, Miyazaki J, Williams SC, Richardson JA, Yanagisawa M: Tie2-Cre transgenic mice: a new model for endothelial cell-lineage analysis in vivo. Dev Biol 2001, 230:230-242

32. Kotch LE, Iyer NV, Laughner E, Semenza GL: Defective vascularization of HIF-1alpha-null embryos is not associated with VEGF deficiency but with mesenchymal cell death. Dev Biol 1999, 209: 254-267

33. Bachmaier K, Toya S, Gao X, Triantafillou T, Garrean S, Park GY, Frey RS, Vogel S, Minshall R, Christman JW, Tiruppathi C, Malik AB: E3 ubiquitin ligase Cblb regulates the acute inflammatory response underlying lung injury. Nat Med 2007, 13:920-926

34. Mirza MK, Sun Y, Zhao YD, Potula HH, Frey RS, Vogel SM, Malik AB, Zhao YY: FoxM1 regulates re-annealing of endothelial adherens junctions through transcriptional control of beta-catenin expression. J Exp Med 2010, 207:1675-1685

35. Han S, Lee SJ, Kim KE, Lee HS, Oh N, Park I, Ko E, Oh SJ, Lee YS, Kim D, Lee S, Lee DH, Lee KH, Chae SY, Lee JH, Kim SJ, Kim HC, Kim S, Kim SH, Kim C, Nakaoka Y, He Y, Augustin HG, Hu J, Song PH, Kim YI, Kim P, Kim I, Koh GY: Amelioration of sepsis by TIE2 activation-induced vascular protection. Sci Transl Med 2016, 8: $335 \mathrm{ra} 55$

36. Ziegler T, Horstkotte J, Schwab C, Pfetsch V, Weinmann K, Dietzel S, Rohwedder I, Hinkel R, Gross L, Lee S, Hu J, Soehnlein O, Franz WM, Sperandio M, Pohl U, Thomas M, Weber C, Augustin HG, Fassler R, Deutsch U, Kupatt C: Angiopoietin 2 mediates microvascular and hemodynamic alterations in sepsis. J Clin Invest 2013, 128:3436-3445

37. Fujita M, Kuwano K, Kunitake R, Hagimoto N, Miyazaki H, Kaneko Y, Kawasaki M, Maeyama T, Hara N: Endothelial cell apoptosis in lipopolysaccharide-induced lung injury in mice. Int Arch Allergy Immunol 1998, 117:202-208

38. Gill SE, Rohan M, Mehta S: Role of pulmonary microvascular endothelial cell apoptosis in murine sepsis-induced lung injury in vivo. Respir Res 2015, 16:109

39. Stevens TC, Ochoa CD, Morrow KA, Robson MJ, Prasain N, Zhou C, Alvarez DF, Frank DW, Balczon R, Stevens T: The Pseudomonas aeruginosa exoenzyme $\mathrm{Y}$ impairs endothelial cell proliferation and vascular repair following lung injury. Am J Physiol Lung Cell Mol Physiol 2014, 306:L915-L924

40. Wang HL, Akinci IO, Baker CM, Urich D, Bellmeyer A, Jain M, Chandel NS, Mutlu GM, Budinger GR: The intrinsic apoptotic pathway is required for lipopolysaccharide-induced lung endothelial cell death. J Immunol 2007, 179:1834-1841

41. Huang X, Zhao YY: Transgenic expression of FoxM1 promotes endothelial repair following lung injury induced by polymicrobial sepsis in mice. PLoS One 2012, 7:e50094

42. Mao SZ, Ye X, Liu G, Song D, Liu SF: Resident endothelial cells and endothelial progenitor cells restore endothelial barrier function after inflammatory lung injury. Arterioscler Thromb Vasc Biol 2015, 35: $1635-1644$

43. Rius J, Guma M, Schachtrup C, Akassoglou K, Zinkernagel AS, Nizet V, Johnson RS, Haddad GG, Karin M: NF-kappaB links innate immunity to the hypoxic response through transcriptional regulation of HIF-1alpha. Nature 2008, 453:807-811

44. Peyssonnaux C, Cejudo-Martin P, Doedens A, Zinkernagel AS, Johnson RS, Nizet V: Cutting edge: essential role of hypoxia inducible factor-1alpha in development of lipopolysaccharideinduced sepsis. J Immunol 2007, 178:7516-7519

45. Eltzschig HK, Sitkovsky MV, Robson SC: Purinergic signaling during inflammation. N Engl J Med 2012, 367:2322-2333
46. Rosenberger P, Schwab JM, Mirakaj V, Masekowsky E, Mager A, Morote-Garcia JC, Unertl K, Eltzschig HK: Hypoxia-inducible factordependent induction of netrin-1 dampens inflammation caused by hypoxia. Nat Immunol 2009, 10:195-202

47. Bartels K, Grenz A, Eltzschig HK: Hypoxia and inflammation are two sides of the same coin. Proc Natl Acad Sci U S A 2013, 110: 18351-18352

48. Ohle SJ, Anandaiah A, Fabian AJ, Fine A, Kotton DN: Maintenance and repair of the lung endothelium does not involve contributions from marrow-derived endothelial precursor cells. Am J Respir Cell Mol Biol 2012, 47:11-19

49. McDonald AI, Shirali AS, Aragon R, Ma F, Hernandez G, Vaughn DA, Mack JJ, Lim TY, Sunshine H, Zhao P, Kalinichenko V, Hai T, Pelegrini M, Ardehali R, Iruela-Arispe ML: Endothelial regeneration of large vessels is a biphasic process driven by local cells with distinct proliferative capacities. Cell Stem Cell 2018, 23:210-225.e6

50. Vohwinkel CU, Hoegl S, Eltzschig HK: Hypoxia signaling during acute lung injury. J Appl Physiol 2015, 119:1157-1163

51. Eckle T, Brodsky K, Bonney M, Packard T, Han J, Borchers CH, Mariani TJ, Kominsky DJ, Mittelbronn M, Eltzschig HK: HIF1A reduces acute lung injury by optimizing carbohydrate metabolism in the alveolar epithelium. PLoS Biol 2013, 11:e1001665

52. McClendon J, Jansing NL, Redente EF, Gandjeva A, Ito Y, Colgan SP, Ahmad A, Riches DWH, Chapman HA, Mason RJ, Tuder RM, Zemans RL: Hypoxia-inducible factor 1alpha signaling promotes repair of the alveolar epithelium after acute lung injury. Am J Pathol 2017, 187:1772-1786

53. Kapitsinou PP, Sano H, Michael M, Kobayashi H, Davidoff O, Bian A, Yao B, Zhang MZ, Harris RC, Duffy KJ, EricksonMiller CL, Sutton TA, Haase VH: Endothelial HIF-2 mediates protection and recovery from ischemic kidney injury. J Clin Invest 2014, 124:2396-2409

54. Branco-Price C, Zhang N, Schnelle M, Evans C, Katschinski DM, Liao D, Ellies L, Johnson RS: Endothelial cell HIF-1alpha and HIF2alpha differentially regulate metastatic success. Cancer Cell 2012, $21: 52-65$

55. Jiang X, Tian W, Tu AB, Pasupneti S, Shuffle E, Dahms P, Zhang P, Cai H, Dinh TT, Liu B, Cain C, Giaccia A, Butcher EC, Simon MC, Semenza GL, Nicolls MR: Endothelial hypoxia-inducible factor- $2 \alpha$ is required for the maintenance of airway microvasculature. Circulation 2019, 139:502-517

56. Dai Z, Li M, Wharton J, Zhu MM, Zhao YY: Prolyl-4 hydroxylase 2 (PHD2) deficiency in endothelial cells and hematopoietic cells induces obliterative vascular remodeling and severe pulmonary arterial hypertension in mice and humans through hypoxia-inducible factor2alpha. Circulation 2016, 133:2447-2458

57. Cowburn AS, Crosby A, Macias D, Branco C, Colaco RD, Southwood M, Toshner M, Crotty Alexander LE, Morrell NW, Chilvers ER, Johnson RS: HIF2alpha-arginase axis is essential for the development of pulmonary hypertension. Proc Natl Acad Sci U S A 2016, 113:8801-8806

58. Ball MK, Waypa GB, Mungai PT, Nielsen JM, Czech L, Dudley VJ, Beussink L, Dettman RW, Berkelhamer SK, Steinhorn RH, Shah SJ, Schumacker PT: Regulation of hypoxia-induced pulmonary hypertension by vascular smooth muscle hypoxia-inducible factor- $1 \alpha$. Am J Respir Crit Care Med 2014, 189:314-324

59. Ariazi JL, Duffy KJ, Adams DF, Fitch DM, Luo L, Pappalardi M, Biju M, DiFilippo EH, Shaw T, Wiggall K, Erickson-Miller C: Discovery and preclinical characterization of GSK1278863 (daprodustat), a small molecule hypoxia inducible factor-prolyl hydroxylase inhibitor for anemia. J Pharmacol Exp Ther 2017, 363:336-347

60. Provenzano R, Besarab A, Sun CH, Diamond SA, Durham JH, Cangiano JL, Aiello JR, Novak JE, Lee T, Leong R, Roberts BK, Saikali KG, Hemmerich S, Szczech LA, Yu KH, Neff TB: Oral hypoxia-inducible factor prolyl hydroxylase inhibitor roxadustat (FG4592) for the treatment of anemia in patients with CKD. Clin J Am Soc Nephrol 2016, 11:982-991 